\title{
Silanediol versus chlorosilanol: hydrolyses and hydrogen-bonding catalyses with fenchole-based silanes
}

\author{
Falco Fox ${ }^{1}$, Jörg M. Neudörff ${ }^{2}$ and Bernd Goldfuss ${ }^{* 1}$
}

\author{
Full Research Paper \\ Address: \\ ${ }^{1}$ Department für Chemie, Institut für Organische Chemie, \\ Greinstrasse 4, 50939 Köln, Germany and 2Department für Chemie, \\ Institut für Organische Chemie, Greinstrasse 6, 50939 Köln, Germany \\ Email: \\ Bernd Goldfuss* - goldfuss@uni-koeln.de \\ * Corresponding author \\ Keywords: \\ hydrogen bonds; hydrolysis; ion pairs; organocatalysis; silanediol
}

Beilstein J. Org. Chem. 2019, 15, 167-186. doi:10.3762/bjoc. 15.17

Received: 26 September 2018

Accepted: 22 December 2018

Published: 18 January 2019

Associate Editor: M. Rueping

(C) 2019 Fox et al.; licensee Beilstein-Institut. License and terms: see end of document.

\begin{abstract}
Biphenyl-2,2'-bisfenchyloxydichlorosilane (7, $\left.\mathrm{BIFOXSiCl}_{2}\right)$ is synthesized and employed as precursor for the new silanols biphenyl-2,2'-bisfenchyloxychlorosilanol (8, $\mathrm{BIFOXSiCl}(\mathrm{OH}))$ and biphenyl-2,2'-bisfenchyloxysilanediol $\left(\mathbf{9}, \mathrm{BIFOXSi}(\mathrm{OH})_{2}\right)$. $\mathrm{BIFOXSiCl}_{2}$ (7) shows a remarkable stability against hydrolysis, yielding silanediol 9 under enforced conditions. A kinetic study for the hydrolysis of dichlorosilane 7 shows a 263 times slower reaction compared to reference bis-(2,4,6-tri-tertbutylphenoxy)dichlorosilane (14), known for its low hydrolytic reactivity. Computational analyses explain the slow hydrolyses of $\operatorname{BIFOXSiCl}_{2}(7)$ to $\operatorname{BIFOXSiCl}(\mathrm{OH})\left(\mathbf{8}, E_{\mathrm{a}}=32.6 \mathrm{kcal} \mathrm{mol}^{-1}\right)$ and $\operatorname{BIFOXSiCl}(\mathrm{OH})(\mathbf{8})$ to $\operatorname{BIFOXSi}(\mathrm{OH})_{2}(\mathbf{9}$, $E_{\mathrm{a}}=31.4 \mathrm{kcal} \mathrm{mol}^{-1}$ ) with high activation barriers, enforced by endo fenchone units. Crystal structure analyses of silanediol 9 with acetone show shorter hydrogen bonds between the $\mathrm{Si}-\mathrm{OH}$ groups and the oxygen of the bound acetone $(\mathrm{OH} \cdots \mathrm{O} 1.88(3)-2.05(2) \AA)$ than with chlorosilanol $8(\mathrm{OH} \cdots 2.16(0) \AA)$. Due to its two hydroxy units, the silanediol 9 shows higher catalytic activity as hydrogen bond donor than chlorosilanol 8, e.g., C-C coupling $N$-acyl Mannich reaction of silyl ketene acetals $\mathbf{1 1}$ with $N$-acylisoquinolinium ions (up to 85\% yield and 12\% ee), reaction of 1-chloroisochroman (18) and silyl ketene acetals 11 (up to 85\% yield and 5\% ee), reaction of chromen-4-one (20) and silyl ketene acetals 11 (up to $98 \%$ yield and $4 \%$ ee).
\end{abstract}

\section{Introduction}

Silanediols are attractive target molecules due their hydrogenbonding capabilities [1-6]. Two synthetic routes are available for syntheses of organosilanediols: If diphenylsilanes are used as building blocks, this route is well suited for syntheses of silanediols with electrophilic functions. In this case, the phenyl groups at the silicon atom are converted by acids (e.g., TFA or $\mathrm{TfOH})$ and following aqueous work-up into silanediols [2,4,7-11]. Another route employs dichlorosilanes, which hydrolyze directly with nucleophiles (e.g., water [12-17] or hydroxide [18-22]) to the corresponding silanediols. While 
hydrolyses of dichlorosilanes have been studied extensively [23-25], hydrolyses of alkoxy dichlorosilanes are much less explored.

Hydrogen bond donor (HBD) catalysis is an emerging field in organic synthesis [26-28], employing, e.g., squaramides [29], (thio)ureas [30,31] and phosphoric acid derivatives [27]. Cyclodiphosph(V)azanes [32-35] and silanediols [1,28,36] are two new hydrogen bonding scaffolds for anion recognition [37] and ion-pair catalysis [6,38]. Since Kondo et al. established silanediol 1 [39] as HBD for anion recognition in 2006, new chiral and achiral silanediols with organosilicon units have been developed by the groups of Franz (2) [40-44] and Mattson $(3,4)$ [45-49] (Figure 1, Scheme 1). While these new catalysts have been proven to be potent HBD catalysts, the syntheses are challenging [47]. Compared to these stable carbon-connected silane-

$$
\mathrm{Ar}^{\mathrm{Ar}^{1}} \mathrm{Si}_{\mathrm{OH}}^{\mathrm{OH}}
$$

$1 \mathrm{Ar}^{1}, \mathrm{Ar}^{2}=$ naphthyl

2a $\mathrm{Ar}^{1}, A r^{2}=$ mesityl

2b $\mathrm{Ar}^{1}=$ mesityl, $\mathrm{Ar}^{2}=4-\mathrm{FC}_{6} \mathrm{H}_{4}$

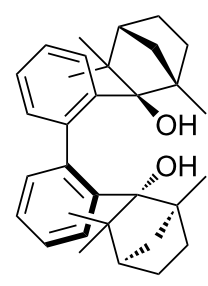

BIFOL (5)

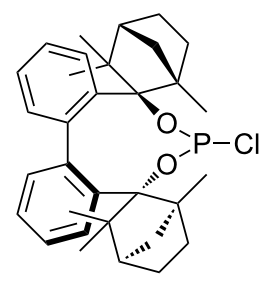

BIFOP-Cl (6)
$3 n=0, \mathrm{R}^{1}, \mathrm{R}^{2}=\mathrm{H}, \mathrm{R}^{3}=\mathrm{Ph}$

$4 n=1, \mathrm{R}^{1}, \mathrm{R}^{2}=\mathrm{Ph}, \mathrm{R}^{3}=\mathrm{H}$

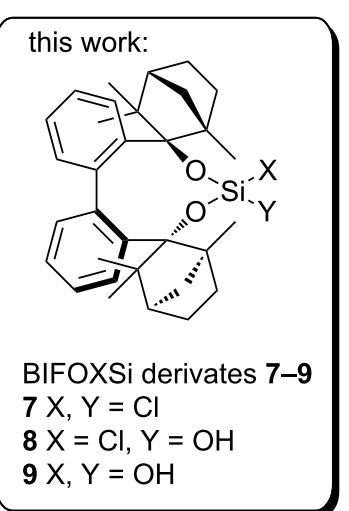

Figure 1: Hydrogen-bonding silanediols, i.e., di(1-naphthyl)silanediol (1) [39], silanediols 2 [41-43], binaphthylsilanediol derivatives 3 [45,46] and 4 $[47,48]$ and novel biphenyl-2,2'-bisfenchyloxydichlorosilane (7), biphenyl-2,2'-bisfenchyloxychlorohydroxysilane (8) and biphenyl-2,2'-bisfenchyloxysilanediol (9) with precursor BIFOL (5) [52] and phosphite derivative BIFOP-Cl (6) [53].

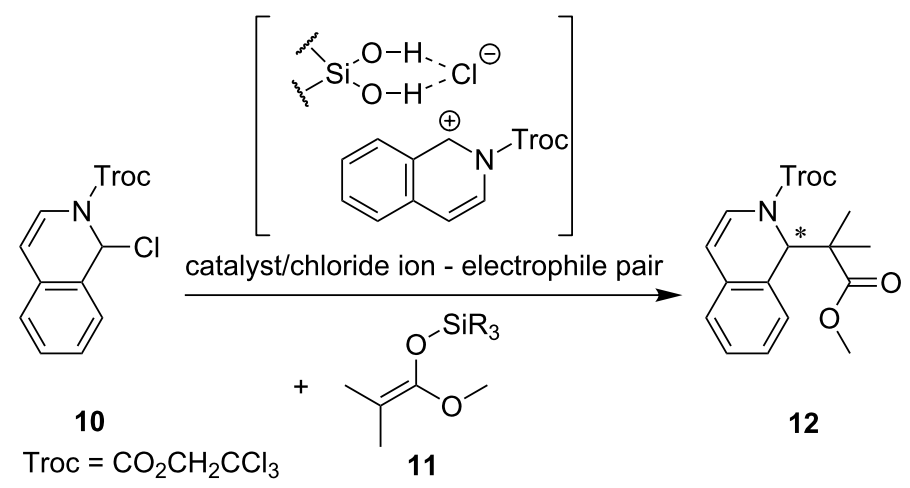

Scheme 1: Hydrogen-bond-catalyzed $\mathrm{N}$-acyl Mannich reaction of in situ-generated isoquinolin derivative 10 with different silyl ketene acetals 11 yielding $\mathrm{C}-\mathrm{C}$ coupling product $12[45,47]$. 
diols, the readily accessible alkoxy silanediols undergo fast condensation reactions which often lead to unknown and insoluble polysiloxanes $[50,51]$.

Previously, our group reports syntheses and applications of symmetric biphenyl-2,2'-bisfenchol (5, BIFOL, Figure 1) $[52,54]$ and it's derivative, the chiral chlorophosphite ligand 6 (BIFOP-Cl, Figure 1), e.g., in Cu-catalyzed 1,4-additions [53], in Pd-catalyzed alkyl-aryl cross coupling reactions [55,56], as well as for organoaluminum fencholate reagents [57]. Unexpected stability against hydrolysis [58] makes BIFOL (5) a potentially promising chiral backbone for new organo silicates, e.g., silanediol 9 (Figure 1). As a silicic acid ester, silanediol 9 should show increased acidity in comparison to $\mathrm{C}-\mathrm{Si}(\mathrm{OH})_{2}$ derivates, e.g., 1-4 [40]. In this work the syntheses of $\mathrm{BIFOXSiCl}_{2}$ (7), $\operatorname{BIFOXSi}(\mathrm{OH})_{2}(\mathbf{9})$ and $\operatorname{BIFOXSiCl}(\mathrm{OH})(\mathbf{8})$ are described. The hydrolytic stability of dichlorosilane $\mathbf{7}$ is investigated in a kinetics study and is compared to analogue dichlorosilanes, i.e., $\mathbf{1 3}$ and $\mathbf{1 4}$ (Scheme 4). UV-vis titration experiments and catalyses are carried out with chlorosilanol $\mathbf{8}$ and silanediol 9, to assess catalytic and anion binding characteristics.

\section{Results and Discussion}

Enantiopure dichlorosilane 7 is readily accessible by lithiation of BIFOL (5) $[28,52,54,59]$ and subsequent reaction with tetrachlorosilane (92\% yield, Scheme 2 ).

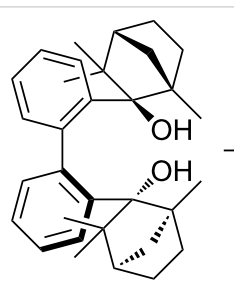

BIFOL (5)

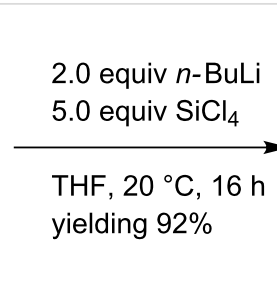

thesis yielding dichlorosilane 7
Unlike the hydrolysis of BIFOP-Cl (6) to BIFOP-OH, the dichlorosilane 7 is not hydrolyzed by aqueous potassium hydroxide solution [53]. The heterolytic reaction of solid $\mathrm{BIFOXSiCl}_{2}(7)$ in an aqueous $\mathrm{KOH}$ solution is negligible ( $<1 \%$ yield, Table 1 , Scheme 3 in a) $\mathrm{H}_{2} \mathrm{O}$ and b) $\mathrm{H}_{2} \mathrm{O} / \mathrm{KOH}$ ). The reluctance against hydrolysis of $\mathrm{BIFOXSiCl}_{2}$ (7) can be explained by the hydrophobic aryl backbone and the fenchyl groups, which result in a decrease of the solubility of $\mathrm{BIFOXSiCl}_{2}$ (7) in water. Thus, a $\mathrm{H}_{2} \mathrm{O} /$ THF mixture is used to increase solubility and yields (Table 1 , Scheme $3 \mathrm{c}$ ). While the solubility of $\mathrm{BIFOXSiCl}_{2}$ (7) in $\mathrm{H}_{2} \mathrm{O}$ /THF greatly increases (clear solution), potassium hydroxide is needed as a strong
Table 1: Hydrolysis of BIFOXSiCl 2 (7) to $\operatorname{BIFOXSi(OH})_{2}(9)$ (Scheme 3 ) in different solvent mixtures, with or without $\mathrm{KOH}$ at different temperatures.

yield ${ }^{\mathrm{a}}[\%]$ in solvent:

\begin{tabular}{lllll}
\hline & a) & b) & c) & d) \\
\hline $\mathrm{T}$ & $\mathrm{H}_{2} \mathrm{O}$ & $\mathrm{H}_{2} \mathrm{O} / \mathrm{KOH}$ & $\mathrm{H}_{2} \mathrm{O} / \mathrm{THF}$ & $\mathrm{H}_{2} \mathrm{O} / \mathrm{THF} / \mathrm{KOH}$ \\
\hline $20^{\circ} \mathrm{C}$ & $<1$ & $<1$ & $<1$ & 14 \\
$50^{\circ} \mathrm{C}$ & $<1$ & $<1$ & 32 & 64 \\
reflux $^{\mathrm{b}}$ & $<1$ & $<1$ & 84 & 53 \\
\hline
\end{tabular}

alsolated yields, reaction conditions: $0.09 \mathrm{mmol} 7,2.5 \mathrm{~mL}$ solvent, $0.9 \mathrm{mmol} \mathrm{KOH}, \mathrm{H}_{2} \mathrm{O} / \mathrm{THF} 1: 1$. breflux conditions are: $\mathrm{H}_{2} \mathrm{O} \approx 100^{\circ} \mathrm{C}$, $\mathrm{H}_{2} \mathrm{O} / \mathrm{KOH} \approx 107^{\circ} \mathrm{C}, \mathrm{H}_{2} \mathrm{O} / \mathrm{THF} \approx 77^{\circ} \mathrm{C}, \mathrm{H}_{2} \mathrm{O} / \mathrm{THF} / \mathrm{KOH} \approx 80^{\circ} \mathrm{C}$.

nucleophile to yield $\mathrm{BIFOXSi}(\mathrm{OH})_{2}(9)$ at $20{ }^{\circ} \mathrm{C}(14 \%$ yield, Table 1, Scheme $3 \mathrm{~d}$ ). By increasing the temperature to $50{ }^{\circ} \mathrm{C}$ the hydrolysis increases, resulting in $32 \%$ yield in $\mathrm{H}_{2} \mathrm{O} / \mathrm{THF}$ and $64 \%$ yield in $\mathrm{H}_{2} \mathrm{O} / \mathrm{THF} / \mathrm{KOH}$ (Table 1 , Scheme 3 ).

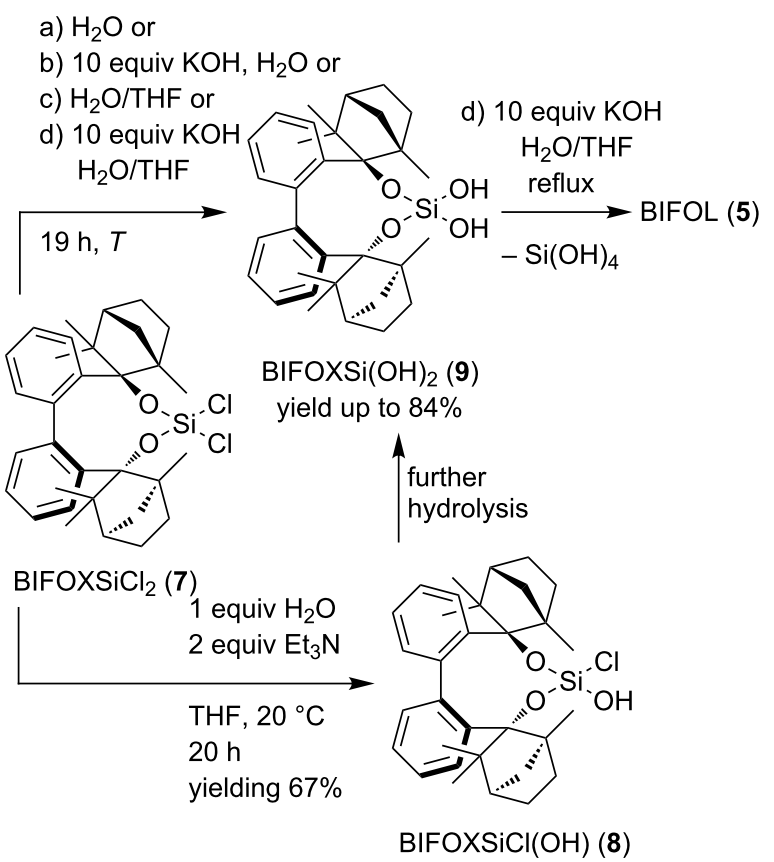

Scheme 3: Hydrolysis of BIFOXSiCl 2 (7) yielding the corresponding silanediol 9 and controlled hydrolysis of $\mathrm{BIFOXSiCl}_{2}(7)$ to $\mathrm{BIFOXSiCl}(\mathrm{OH})(\mathbf{8})$. For solvent mixtures and temperatures see Table 1.

At reflux conditions in $\mathrm{H}_{2} \mathrm{O} / \mathrm{THF}$, but without potassium hydroxide, $\operatorname{BIFOXSi}(\mathrm{OH})_{2}(9)$ is isolated in $89 \%$ yield, while with $\mathrm{KOH}$, just $53 \%$ yield is achieved (Table 1). The lower yield of silanediol 9, at $\mathrm{H}_{2} \mathrm{O} / \mathrm{THF} / \mathrm{KOH}$ reflux conditions, can be explained by the further hydrolysis to $\operatorname{BIFOL~(5,~Scheme~3).~}$ Under the conditions described in Table 1, the monohydroxy 
compound $\mathrm{BIFOXSiCl}(\mathrm{OH})(8)$ cannot be isolated as an intermediate. For the synthesis of chlorosilanol $\mathbf{8}$ optimized reaction conditions are necessary. Here, 1 equiv of water and 2 equiv of triethylamine (relative to dichlorosilane 7) are added to a THF solution at $20^{\circ} \mathrm{C}$. $\mathrm{BIFOXSiCl}(\mathrm{OH})(\mathbf{8})$ is isolated in $67 \%$ yield (Scheme 3).

\section{Hydrolysis studies}

To assess the stability of dichlorosilane 7 , its hydrolysis relative to established silanediol motifs, i.e., di-tertbutoxydichlorosilane $\left(\left(\left(\mathrm{CH}_{3}\right)_{3} \mathrm{CO}\right)_{2} \mathrm{SiCl}_{2}\right)$ [50], di(1-naphthyl)dichlorosilane (13) [39] and bis(2,4,6-tri-tert-butylphenoxy)dichlorosilane (14) $[60,61]$ is examined (Scheme 4). In close analogy to $\mathrm{BIFOXSiCl}_{2}$ (7), di-tert-butoxydichlorosilane is substituted with tertiary alkoxy groups. While the close analogy of $\mathrm{BIFOXSiCl}_{2}(7)$ and $\left(\left(\mathrm{CH}_{3}\right)_{3} \mathrm{CO}\right)_{2} \mathrm{SiCl}_{2}$ would make a comparison of these two dichlorosilanes preferable, the instability of the latter against hydrolyses and temperature resulting in further condensation products [50,51], leaves no comparison possible.

At $\mathrm{H}_{2} \mathrm{O}$ /THF reflux conditions, the hydrolysis of dichlorosilane 13 yields silanediol 1 with $>99 \%$ yield, after a reaction time of two seconds (Scheme 4, addition of $\mathrm{H}_{2} \mathrm{O}$, with instant extraction with $\mathrm{Et}_{2} \mathrm{O}$ ). The stability of dichlorosilane 14, which has been previously reported by Spirk et al. [60], has been found to be higher than that of dichlorosilane $\mathbf{1 3}$ under the same condi-

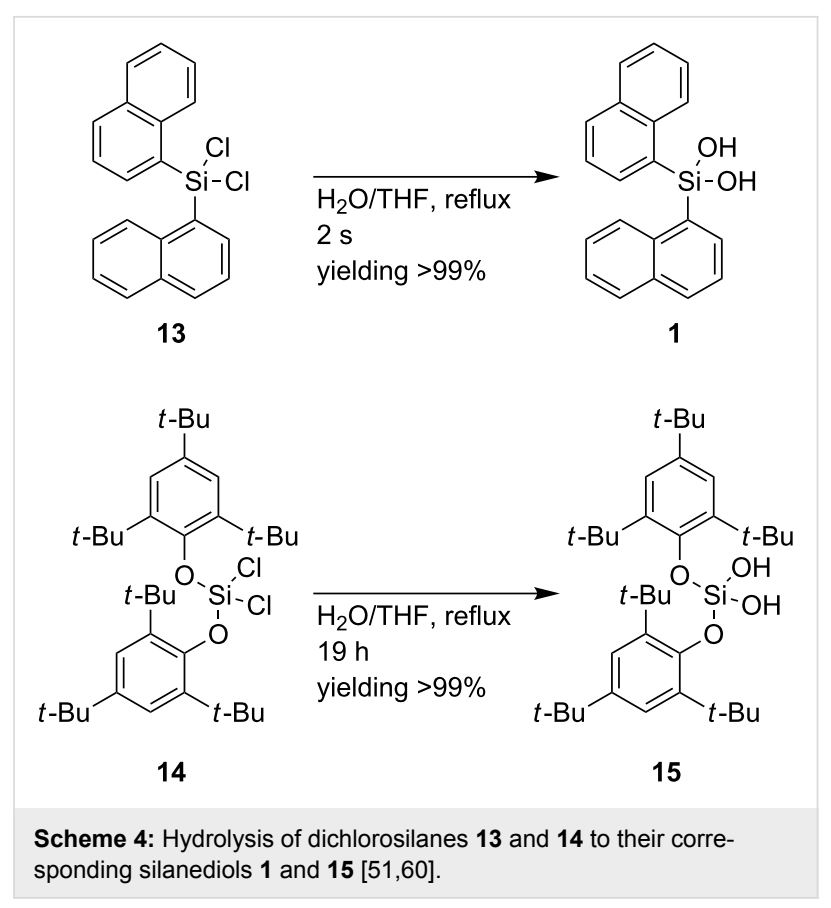

tions $\left(\mathrm{H}_{2} \mathrm{O} / \mathrm{THF}\right.$ reflux) resulting in $>99 \%$ yield after $100 \mathrm{~min}$ (Figure 2, red squares). The hydrolysis of dichlorosilanes 7 and 14 to the corresponding silanediols 9 (Scheme 3) and 15 (Scheme 4) is investigated further (Figure 2). The conversion of dichlorosilane 14 to silanediol $\mathbf{1 5}$ is completed (yield $>99 \%$ )

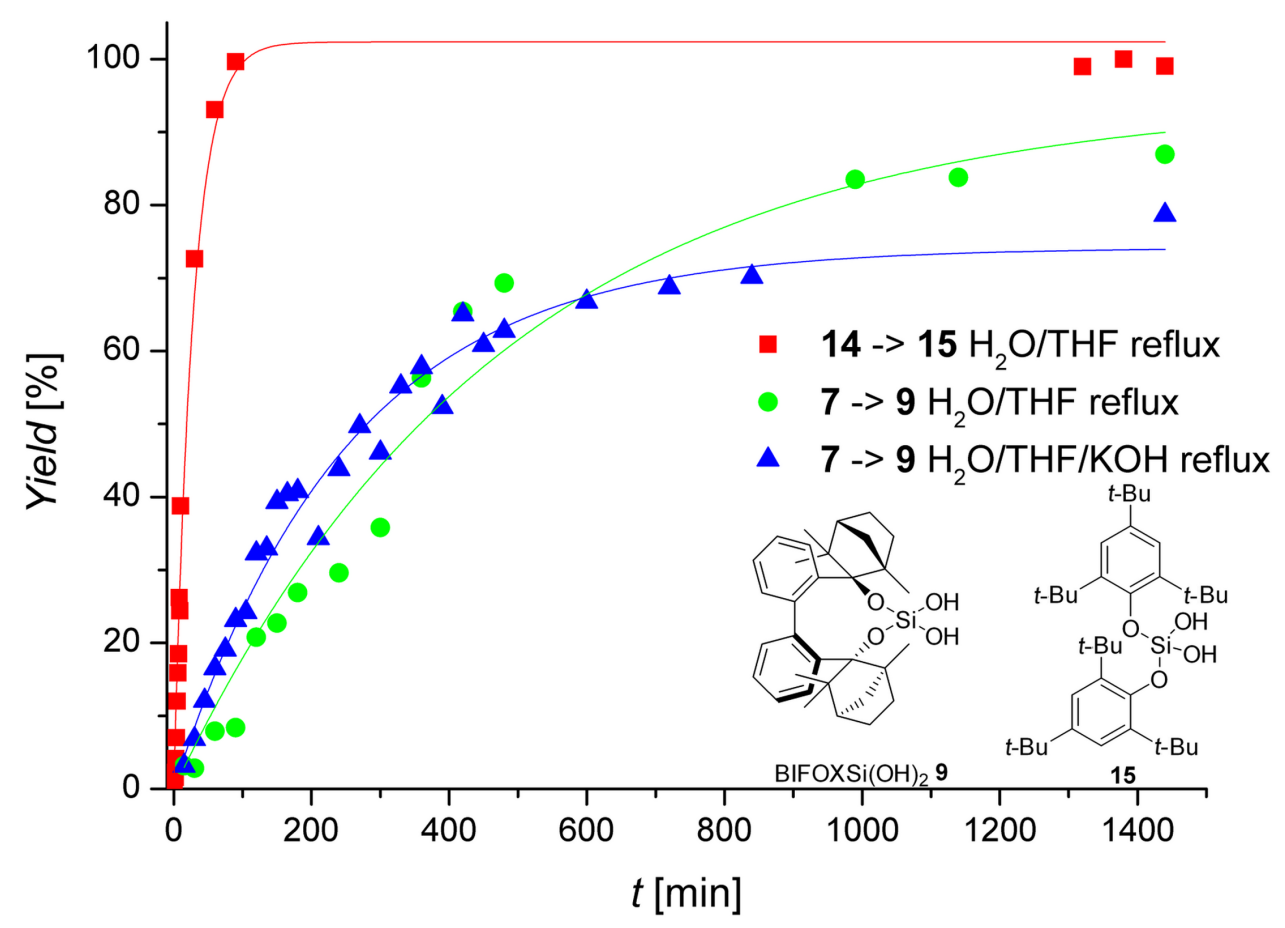

Figure 2: Hydrolyses of dichlorosilane 7 and 14 to $\mathrm{BIFOXSi}(\mathrm{OH})_{2}(\mathbf{9}$, green circle) and bis(2,4,6-tri-tert-butylphenoxy)silanediol (15, red square) in $\mathrm{H}_{2} \mathrm{O} / \mathrm{THF}$ reflux and BIFOXSi $(\mathrm{OH})_{2}\left(\mathbf{9}\right.$, blue triangle) in $\mathrm{H}_{2} \mathrm{O} / \mathrm{THF} / \mathrm{KOH}$ reflux conditions. Isolated yields are plotted against reaction time (Table 1 , Scheme 3 and Scheme 4). Reflux conditions are: $\mathrm{H}_{2} \mathrm{O} / \mathrm{THF} \approx 77^{\circ} \mathrm{C}, \mathrm{H}_{2} \mathrm{O} / \mathrm{THF} / \mathrm{KOH} \approx 80^{\circ} \mathrm{C}$. 
after 100 minutes at $\mathrm{H}_{2} \mathrm{O}$ /THF reflux conditions (Figure 2, red square). The hydrolysis of $\mathrm{BIFOXSiCl}_{2}$ (7) on the other hand is slower at the same conditions $(24 \mathrm{~h}$ for $84 \%$ yield of $\operatorname{BIFOXSi}(\mathrm{OH})_{2}$ (9, Figure 2, green circle). With $\mathrm{H}_{2} \mathrm{O} / \mathrm{THF} /$ $\mathrm{KOH}$ reflux conditions the initial reaction is found to be slightly faster, but resulting in a saturation at a lower yield of BIFOXSi $(\mathrm{OH})_{2}(\mathbf{9}$, Figure 2, blue triangle, $70 \%$ yield $)$, caused by a starting decomposition of $\operatorname{BIFOXSi}(\mathrm{OH})_{2}(\mathbf{9})$ to $\mathrm{BIFOL}(\mathbf{5})$ and $\mathrm{Si}(\mathrm{OH})_{4}$ (Scheme 3). To quantify the reactivity of the dichlorosilanes $\mathbf{7}$ and 14, a higher concentration of water (solvent) or hydroxide (10 equiv) is used (Table 2 ), resulting in a pseudo first order reaction.

Table 2: Hydrolyses of dichlorosilanes 7 and 14 to the corresponding silanediols 9 and 15 (Figure 3 , Scheme 3 and Scheme 4, absolute reaction constant $k$ and relative reaction constant $\left.k_{\text {rel }}\right)$.

\begin{tabular}{lll} 
reaction & $k^{\mathrm{a}}\left[\mathrm{min}^{-1}\right]$ & $k_{\mathrm{rel}^{\mathrm{b}}}\left[\mathrm{min}^{-1}\right]$ \\
\hline $\mathbf{1 4 \mathrm { H } _ { 2 } \mathrm { O } / \text { THF reflux }}$ & 0.848 & 263 \\
$\mathbf{7 \mathrm { H } _ { 2 } \mathrm { O } / \text { THF/KOH reflux }} \mathrm{c}$ & 0.005 & 1.5 \\
$\mathbf{7 \mathrm { H } _ { 2 } \mathrm { O } / \text { THF reflux }}$ & 0.003 & 1
\end{tabular}

${ }^{a} k$ is determined with $\ln \left(\left[\mathrm{A}_{0}\right] /\left[\mathrm{A}_{\mathrm{t}}\right]\right)=k * t$ and plotted in Figure $3 .{ }^{b} k_{\text {rel }}$ is normalized on the slowest hydrolysis reaction of $\mathrm{BIFOXSiCl}_{2}(7)$ in $\mathrm{H}_{2} \mathrm{O} / \mathrm{THF}$ reflux conditions (Scheme 2 , Scheme 3 ). ${ }^{C}$ Reflux conditions are: $\mathrm{H}_{2} \mathrm{O} / \mathrm{THF} \approx 77^{\circ} \mathrm{C}, \mathrm{H}_{2} \mathrm{O} / \mathrm{THF} / \mathrm{KOH} \approx 80^{\circ} \mathrm{C}$.
To remove the influence of the decomposition of silanediol 9 , just the reaction time from 0 to $600 \mathrm{~min}$ is considered. Compared to established dichlorosilanes, the observed stability of $\mathrm{BIFOXSiCl}_{2}(7)$ is clearly apparent from those studies (Figure 2 and Figure 3). Dichlorosilane 14, which is known to show a comparably high resistancy against hydrolysis [60], exhibits a much faster hydrolysis reaction $\left(k_{\mathrm{rel}}=263 \mathrm{~min}^{-1}\right.$, Table 2$)$ at $\mathrm{H}_{2} \mathrm{O} / \mathrm{THF}$ reflux conditions than $\mathrm{BIFOXSiCl}_{2}$ (7). With $\mathrm{KOH}$, the reaction rate of the hydrolysis of $\mathrm{BIFOXSiCl}_{2}(7)$ is just slightly increased $\left(k_{\text {rel }}=1.5 \mathrm{~min}^{-1}\right.$, Table 2$)$.

\section{Computational analyses}

Nucleophilic substitution at silicon is already discussed with $\mathrm{S}_{\mathrm{N}} 2$ mechanism, following a backside attack opposite of the leaving group, as well as a front side attack near the leaving group [62-68]. A backside attack at the silicon in dichlorosilane $\mathbf{7}$ and monochlorosilanol $\mathbf{8}$ is blocked by the backbone, making a consideration of the mechanism not necessary. A mechanism with a pentacoordination at the silicon is assumed for the hydrolyses of $\mathrm{BIFOXSiCl}_{2}(7)$ to $\mathrm{BIFOXSiCl}(\mathrm{OH})(8)$ as intermediate and $\mathrm{BIFOXSI}(\mathrm{OH})_{2}(9)$ as product [65-67]. Two pathways (front attack mechanism (front) or side attack mechanism (side)) for the approaching water molecule are considered (Scheme 5).

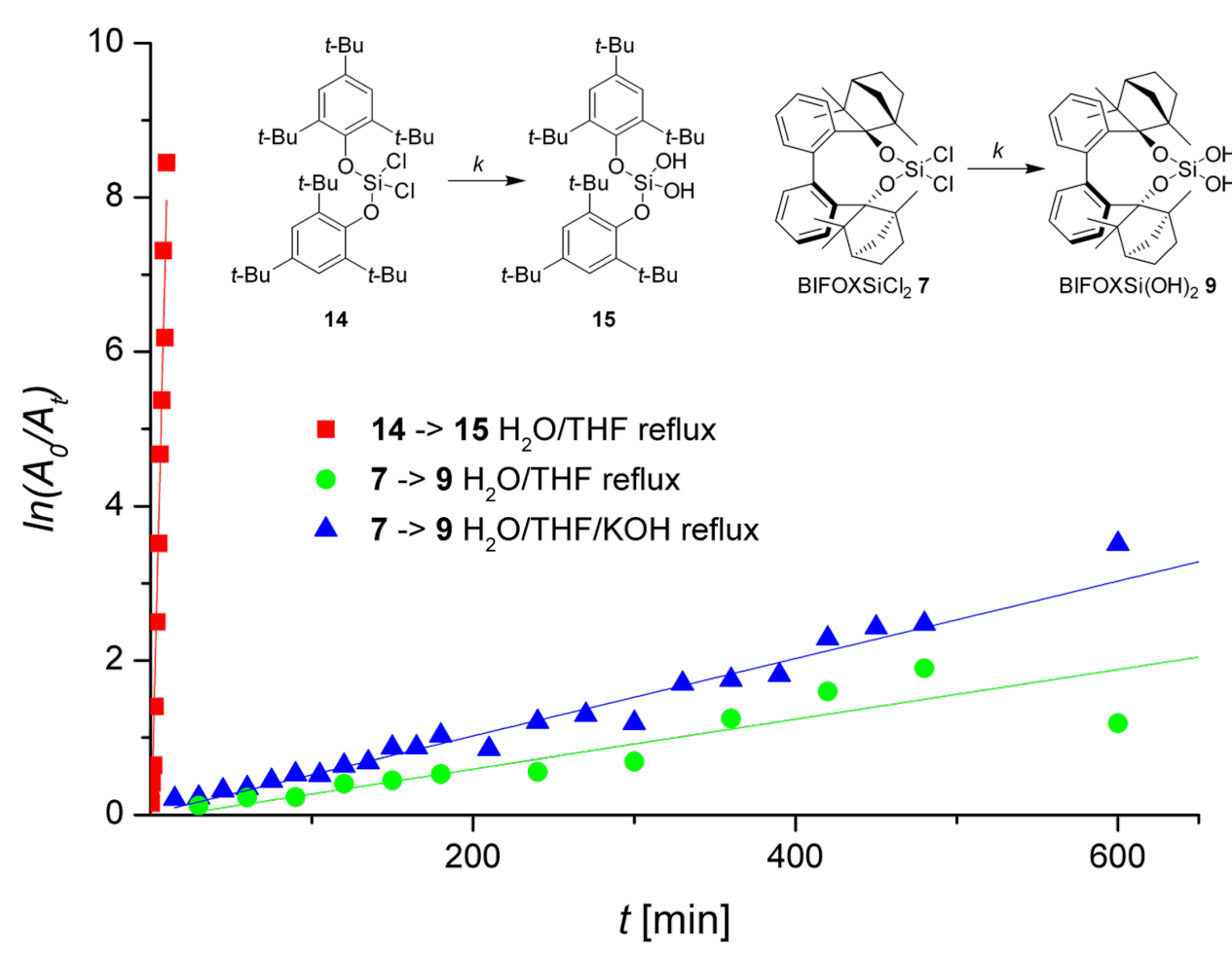

Figure 3: Hydrolyses of BIFOXSiCl 2 (7) to BIFOXSi(OH) 2 (9, green circle), bis(2,4,6-tri-tert-butylphenoxy)dichlorosilane (14) to bis $(2,4,6$-tri-tertbutylphenoxy)silanediol (15, red square) in $\mathrm{H}_{2} \mathrm{O} / \mathrm{THF}$ reflux and $\mathrm{BIFOXSiCl}_{2}(\mathbf{7})$ to $\mathrm{BIFOXSi}(\mathrm{OH})_{2}\left(9\right.$, blue triangle) $\mathrm{H}_{2} \mathrm{O} / \mathrm{THF} / \mathrm{KOH}$ reflux conditions (Scheme 3 and Scheme 4). Reaction constants are evaluated with $\ln \left(\left[A_{0}\right] /\left[A_{\mathrm{t}}\right]\right)=k \cdot t$ for a pseudo-first-order reaction plotted against reaction time (Table 2). Reflux conditions are: $\mathrm{H}_{2} \mathrm{O} / \mathrm{THF} \approx 77^{\circ} \mathrm{C}, \mathrm{H}_{2} \mathrm{O} / \mathrm{THF} / \mathrm{KOH} \approx 80^{\circ} \mathrm{C}$. 
front attack of water (front):

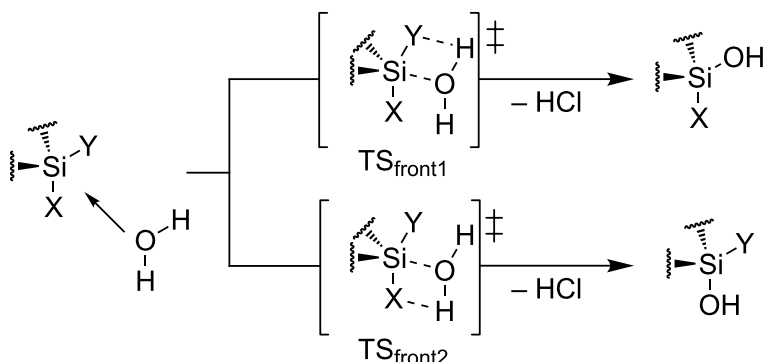

side attack of water (side):<smiles>[X][Si]1(Cl)C[13C]1OP</smiles>

$\mathrm{X}, \mathrm{Y}=\mathrm{Cl}, \mathrm{OH}$

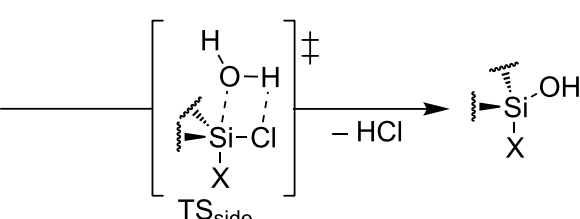

Scheme 5: Two investigated pathways for the hydrolysis of the dichlorosilanes. Front attack mechanism (front) between the two chloro substituents or side attack mechanism (side) between one chloro and both additional substituents (TS = transition structure) [62-68].

In both, front attack and side attack, the attacking water molecule is in plane with the $\mathrm{Cl}-\mathrm{Si}-\mathrm{Cl}$ unit for the first hydrolysis step. For the second hydrolysis step, analogue pathways are considered. These trajectories lead to three transition structures each, for the hydrolysis of $\mathrm{BIFOXSiCl}_{2}$ (7) and BIFOXSiCl(OH) (8, Figure 4).
Geometry optimizations and frequency computations are performed in gas phase with B3LYP-D3BJ/6-31G(d) at $298 \mathrm{~K}$. For single point energies, M06-2X-D3/6-311++G(d,p) in the solvent THF with the PCM model is used $[69,70]$. The free Gibbs energies of the respective structures are discussed. The activation energy $\left(E_{\mathrm{a}}\right)$ is the difference between the educt and the TS and the reaction energy $\left(E_{\mathrm{r}}\right)$ is the difference between the educts and products of the respective steps. The mechanism of hydrolysis, only one molecule of water per hydrolysis step is considered. Additional interactions by THF and water are only considered by the PCM model. Starting with $\mathrm{BIFOXSiCl}_{2}$ (7), the side and front 1 attack mechanism are resulting in $\operatorname{BIFOXSiCl}(\mathrm{OH})$ $\mathbf{8}_{\text {eq. }}$. The front2 attack mechanism results in $\operatorname{BIFOXSiCl}(\mathrm{OH})$ $\mathbf{8}_{\mathbf{a x}}$ (Figure 5).

For the TS of the front 1 attack mechanism, the lowest activation energy $\left(E_{\mathrm{a}}=32.6 \mathrm{kcal} \mathrm{mol}^{-1}\right.$, Table 3, entry 1, Figure 5 and Figure 6$)$ is found, closely followed by the front 2 attack mechanism $\left(E_{\mathrm{a}}=33.2 \mathrm{kcal} \mathrm{mol}^{-1}\right.$, Table 3, entry 2, Figure 5 and Figure 7). The side attack mechanism leads to the highest TS for the first hydrolysis step of $\mathrm{BIFOXSiCl}_{2}$ (7) to $\operatorname{BIFOXSiCl}(\mathrm{OH}) \mathbf{8}_{\text {eq }}\left(E_{\mathrm{a}}=37.3 \mathrm{kcal} \mathrm{mol}^{-1}\right.$, Table 3 , entry 3 , Figure 5 and Figure 8). $\mathrm{BIFOXSiCl}(\mathrm{OH}) \mathbf{8}_{\mathbf{a x}}$ is found to be the more stable isomer with a reaction energy $E_{\mathrm{r}}$ of $-4.4 \mathrm{kcal} \mathrm{mol}^{-1}$, compared to $\operatorname{BIFOXSiCl}(\mathrm{OH}) \mathbf{8}_{\mathbf{e q}}$ with a $E_{\mathrm{r}}$ of $-1.7 \mathrm{kcal} \mathrm{mol}^{-1}\left(\Delta E_{\mathrm{r}}=2.7 \mathrm{kcal} \mathrm{mol}^{-1}\right.$, Table 3, entries 1 and 2 , Figure 5), as it is found as the only isomere in crystal structure analysis (Figure 13). For the second hydrolysis step from $\operatorname{BIFOXSiCl}(\mathrm{OH}) \mathbf{8}_{\mathbf{a x}}$ to $\operatorname{BIFOXSi}(\mathrm{OH})_{2}(\mathbf{9})$, the side attack

TS for BIFOXSiCl 2 :

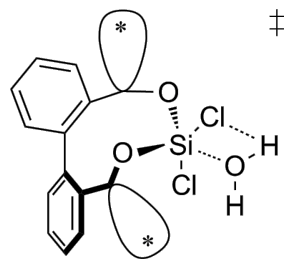

$\mathrm{TS}_{\text {front1 }} 7$

TS for $\mathrm{BIFOXSiCl}(\mathrm{OH})$ :

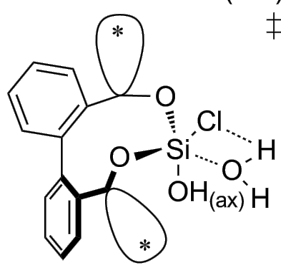

$\mathrm{TS}_{\text {front1 }} \mathbf{8}_{\mathrm{ax}}$

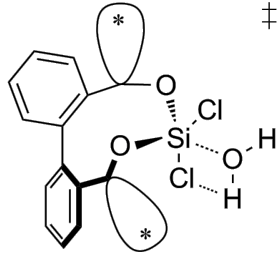

$\mathrm{TS}_{\text {front2 }} 7$

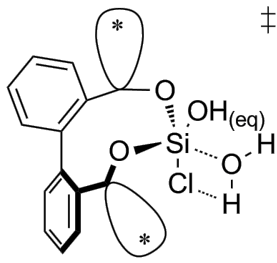

$\mathrm{TS}_{\text {front2 }} \mathbf{8}_{\text {eq }}$

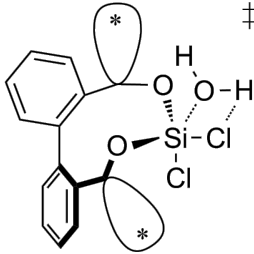

$\mathrm{TS}_{\text {side }} 7$

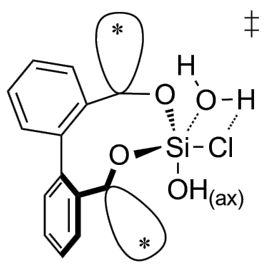

$\mathrm{TS}_{\text {side }} \mathbf{8}_{\mathrm{ax}}$

Figure 4: Three transition structures each, for the hydrolysis of $\mathrm{BIFOXSiCl}_{2}(7)$ and $\mathrm{BIFOXSiCl}(\mathrm{OH})(8)$ considering two possible configuration isomers of $\mathrm{BIFOXSiCl}(\mathrm{OH})(\mathbf{8})$. For $\mathbf{8}_{\mathrm{ax}}$ the $\mathrm{OH}$ group is parallel situated to the biaryl axis. For $\mathbf{8}_{\mathrm{eq}}$ the $\mathrm{OH}$ group is orthogonal oriented to the biaryl axis. The fenchyl groups are abbreviated with $\left({ }^{*}\right)$ for more clarity. 


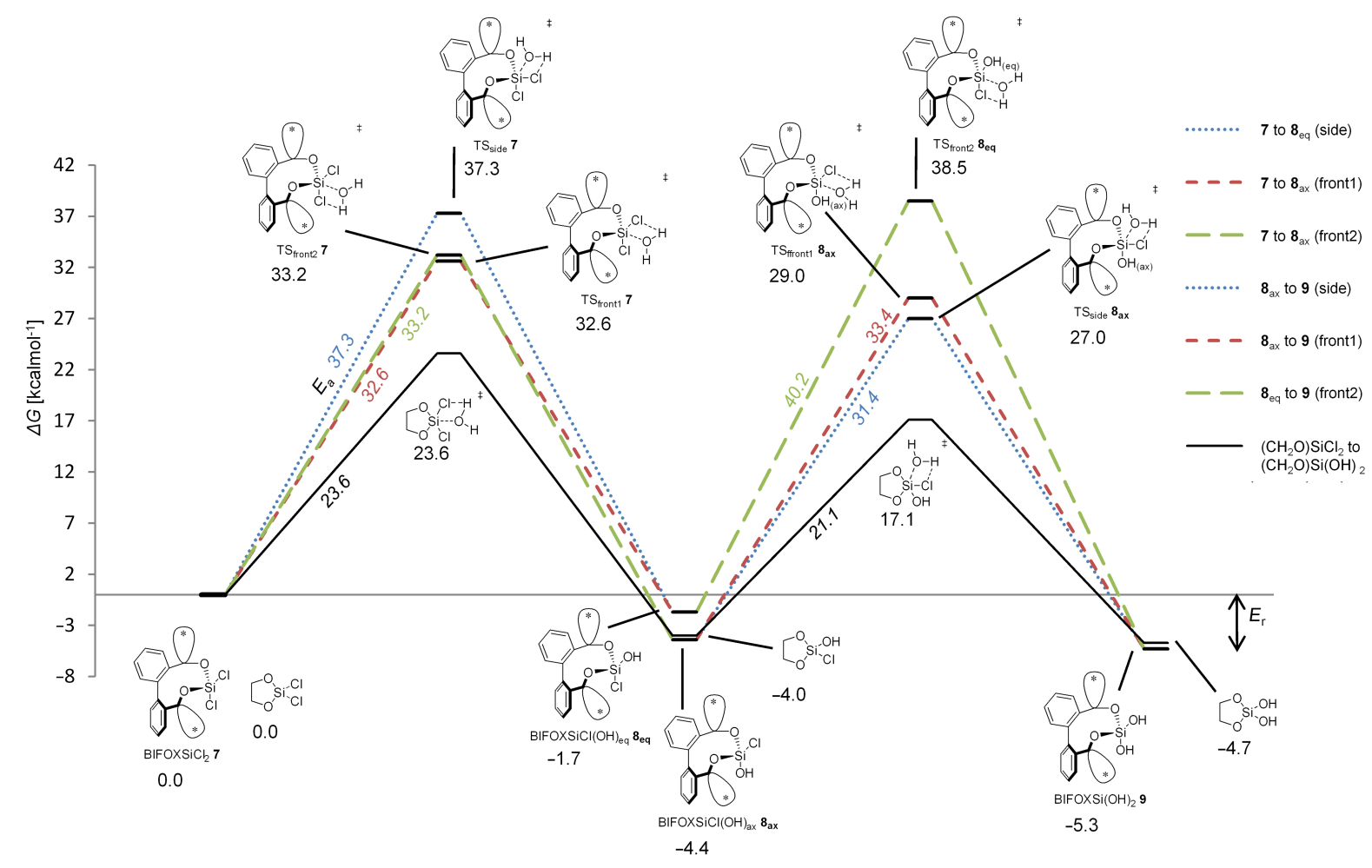

Figure 5: Computed hydrolyses of $\mathrm{BIFOXSiCl}_{2}(\mathbf{7})$ to $\mathrm{BIFOXSiCl}(\mathrm{OH}) \mathbf{8}_{\mathrm{ax}}$ and $\mathrm{BIFOXSiCl}(\mathrm{OH}) \mathbf{8}_{\text {eq }}$ and subsequent computed hydrolysis to $\mathrm{BIFOXSi}(\mathrm{OH})_{2}(9)$ and comparison with glycoxydichlorosilane. The activation energy $\left(E_{\mathrm{a}}\right)$ is the difference of the free Gibbs energy of the educt and the TS and the reaction energy $\left(E_{\mathrm{r}}\right)$ is the difference the free Gibbs energies of the educts and products of the respective steps side and front 1 resulting in $\mathrm{BIFOXSiCl}(\mathrm{OH}) \mathbf{8}_{\mathbf{e q}}$, front2 results in $\mathrm{BIFOXSiCl}(\mathrm{OH}) \mathbf{8}_{\mathbf{a x}}$. From BIFOXSiCl(OH) $\mathbf{8}_{\text {eq }}$ only front2 is a possible path to $\mathrm{BIFOXSi}(\mathrm{OH})_{2}(\mathbf{9})$. From $\mathrm{BIFOXSiCl}(\mathrm{OH}) \mathbf{8}_{\mathrm{ax}}$ front1 and side are possible paths to $\mathrm{BIFOXSi}(\mathrm{OH})_{2}(\mathbf{9}$, Table 3, Figure 4, Scheme 5$)$. Reaction energies are $\left(E_{\mathrm{r}}\right)$ in kcal mol ${ }^{-1}$, activation energies are $\left(E_{\mathrm{a}}\right)$ in $\mathrm{kcal} \mathrm{mol}^{-1}$ and italic.

Table 3: Computed ${ }^{\mathrm{a}}$ activation energies and reaction energies $\left(E_{\mathrm{a}}\right.$ and $\left.E_{\mathrm{r}}\left[\mathrm{kcal} \mathrm{mol}^{-1}\right]\right)$ and imaginary frequencies $\left(\mathrm{v}\right.$ [cm $\left.\left.{ }^{-1}\right]\right)$ of the transition structure (TS) for the hydrolysis of dichlorosilane $7,8,13,\left[\mathrm{CH}_{2} \mathrm{O}_{2} \mathrm{SiCl}_{2}\right.$ and $\mathrm{SiCl}_{4}$ to the corresponding mono- and diols.

\begin{tabular}{|c|c|c|c|c|c|}
\hline entry & reaction & TS & $v$ & $E_{\mathrm{a}}$ & $E_{\mathrm{r}}$ \\
\hline $1^{b}$ & 7 to $8_{\mathrm{eq}}$ & $\mathrm{TS}_{\text {front1 } 1} 7$ & -206.23 & 32.6 & -1.7 \\
\hline 2 & 7 to $8 \mathrm{ax}$ & $\mathrm{TS}_{\text {front2 }} 7$ & -221.44 & 33.2 & -4.4 \\
\hline 3 & 7 to $8_{\text {eq }}$ & $\mathrm{TS}_{\text {side }} 7$ & -189.66 & 37.3 & -1.7 \\
\hline 4 & 8 ax to 9 & $\mathrm{TS}_{\text {front1 }} 8_{\mathrm{ax}}$ & -208.01 & 33.4 & -5.3 \\
\hline 5 & $8_{\text {eq }}$ to 9 & $\mathrm{TS}_{\text {front2 }} \mathbf{8}_{\mathrm{eq}}$ & -242.41 & 40.2 & -5.3 \\
\hline $6^{b}$ & 8 ax to 9 & $\mathrm{TS}_{\text {side }} 8_{\mathrm{ax}}$ & -162.28 & 31.4 & -5.3 \\
\hline $7^{b}$ & 13 to $13 \mathrm{CIOH}$ & $\mathrm{TS}_{\text {front }} 13$ & -167.52 & 27.7 & -1.1 \\
\hline 8 & 13 to $13 \mathrm{CIOH}$ & $\mathrm{TS}_{\text {side }} 13$ & -176.02 & 35.4 & -1.1 \\
\hline $9^{b}$ & $13_{\mathrm{CIOH}}$ to 1 & $\mathrm{TS}_{\text {front }} 13_{\mathrm{CIOH}}$ & -137.30 & 29.1 & 1.5 \\
\hline 10 & $13_{\mathrm{CIOH}}$ to 1 & $\mathrm{TS}_{\text {side }} 13_{\mathrm{ClOH}}$ & -119.75 & 29.9 & 1.5 \\
\hline 11 & {$\left[\mathrm{CH}_{2} \mathrm{O}\right]_{2} \mathrm{SiCl}_{2}$ to $\left[\mathrm{CH}_{2} \mathrm{O}_{2} \mathrm{SiClOH}\right.$} & & -542.44 & 23.6 & -4.0 \\
\hline 12 & {$\left[\mathrm{CH}_{2} \mathrm{O}\right]_{2} \mathrm{SiClOH}$ to $\left[\mathrm{CH}_{2} \mathrm{O}\right]_{2} \mathrm{Si}(\mathrm{OH})_{2}$} & & -189.64 & 21.1 & -4.7 \\
\hline 13 & $\mathrm{Cl}_{2} \mathrm{SiCl}_{2}$ to $\mathrm{Cl}_{2} \mathrm{SiClOH}$ & & -415.78 & 28.4 & -5.4 \\
\hline 14 & $\mathrm{Cl}_{2} \mathrm{SiClOH}$ to $\mathrm{Cl}_{2} \mathrm{Si}(\mathrm{OH})_{2}$ & & -209.82 & 25.0 & -9.3 \\
\hline 15 & $(\mathrm{OH})_{2} \mathrm{SiCl}_{2}$ to $(\mathrm{OH})_{2} \mathrm{SiClOH}$ & & -145.49 & 20.9 & -3.4 \\
\hline 16 & $(\mathrm{OH})_{2} \mathrm{SiClOH}$ to $(\mathrm{OH})_{2} \mathrm{Si}(\mathrm{OH})_{2}$ & & -128.55 & 20.8 & -4.8 \\
\hline
\end{tabular}

aM06-2X-D3/6-311++G(d.p)(PCM=THF)//B3LYP-D3BJ/6-31G(d) at $298 \mathrm{~K}$. b Favored reaction structures are bolted. 
mechanism leads to the lowest TS $\left(E_{\mathrm{a}}=31.4 \mathrm{kcal} \mathrm{mol}^{-1}\right.$, Table 3, entry 6, Figure 5, Figure 9), followed by the front 1 attack mechanism $\left(E_{\mathrm{a}}=33.4 \mathrm{kcal} \mathrm{mol}^{-1}\right.$, Table 3, entry 4 , Figure 5, Figure 10) leading to product BIFOXSi $(\mathrm{OH})_{2}(\mathbf{9})$.

From BIFOXSiCl(OH) $\mathbf{8}_{\text {eq }}$ only the front attack mechanism $\mathrm{TS}_{\text {front2 }} \mathbf{8}_{\text {eq }}$ is possible, which also leads to $\operatorname{BIFOXSi}(\mathrm{OH})_{2}(\mathbf{9})$, but with the highest $E_{\mathrm{a}}\left(40.2 \mathrm{kcal} \mathrm{mol}^{-1}\right.$, Table 3, entry 5 , Figure 5 and Figure 11). In accordance with the crystal structure analysis of $\mathrm{BIFOXSiCl}(\mathrm{OH})(\mathbf{8}$, Figure 13), it can be seen that the more stable isomer $\mathrm{BIFOXSiCl}(\mathrm{OH}) \mathbf{8}_{\mathbf{a x}}$ corresponds to the synthesized isomer. Considering the lowest $E_{\mathrm{a}}$ for both steps, the first hydrolysis step is the rate-determining step (7 to $\mathbf{8}_{\text {eq }}, \mathrm{TS}_{\text {front1 }} \mathbf{7} E_{\mathrm{a}}=32.6 \mathrm{kcal} \mathrm{mol}^{-1}$ vs $\mathbf{8}_{\mathbf{a x}}$ to $\mathbf{9}, \mathrm{TS}_{\text {side }} \mathbf{8}_{\mathbf{a x}}$ $E_{\mathrm{a}}=31.4 \mathrm{kcal} \mathrm{mol}^{-1}$, Table 3, entries 1 and 6 , Figure 6 and Figure 9), which agrees with the experimental hydrolysis. Under $\mathrm{H}_{2} \mathrm{O} / \mathrm{THF}$ reflux conditions, no $\operatorname{BIFOXSiCl}(\mathrm{OH})(8)$ has been isolated, but has to be synthesized separately (Scheme 3, Figure 2 and Figure 3). Both front attack TS have much lower energy, than the TS resulting by side attack mechanism, for the first hydrolysis step $\left(\mathrm{TS}_{\text {front2 }} 7 E_{\mathrm{a}}=33.2 \mathrm{kcal} \mathrm{mol}^{-1}, \mathrm{TS}_{\text {front1 }} 7\right.$ $E_{\mathrm{a}}=32.6 \mathrm{kcal} \mathrm{mol}^{-1} \mathrm{vs} \mathrm{TS}$ side $7 \mathrm{E}_{\mathrm{a}}=37.3 \mathrm{kcal} \mathrm{mol}^{-1}$, Table 3 , entries 1-3, Figures 6-8). Responsible for the lower $E_{\mathrm{a}}$ is an additional stabilization by an interaction of the remaining chloro atom to the attacking water (dotted line to the $\mathrm{Cl}(\mathrm{ax})$ Figure 6 and $\mathrm{Cl}(\mathrm{eq})$ Figure 7). The small energy difference for the $\mathrm{TS}_{\text {front1 }} 7$ and $\mathrm{TS}_{\text {front2 }} 7$ is to explained by additional $\mathrm{C}-\mathrm{H}$ interactions between the fenchyl groups to the leaving chloride (four

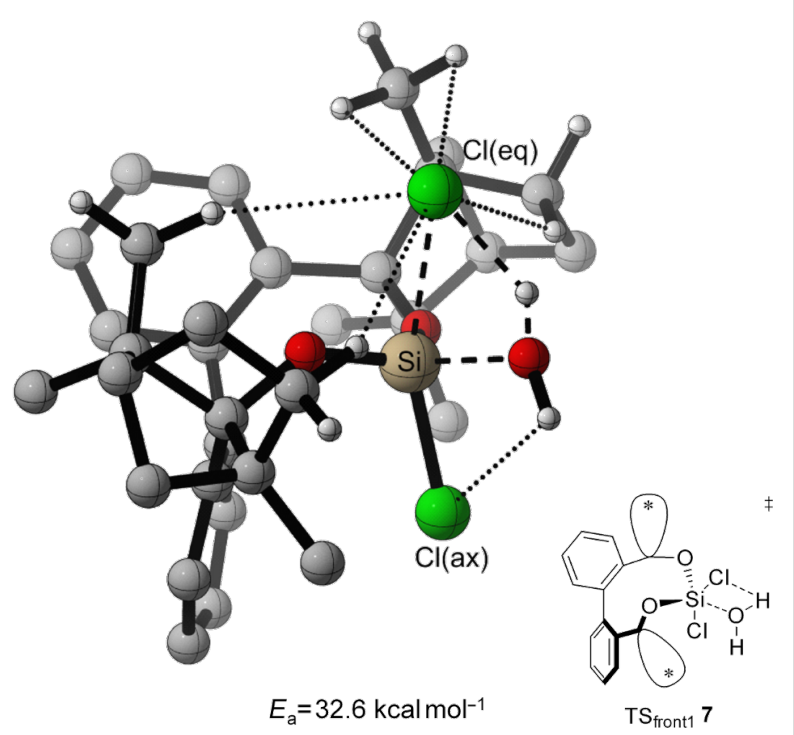

Figure 6: Transition state leading to $\mathbf{8}_{\text {eq }}$ following front 1 attack $\left(E_{\mathrm{a}}=32.6 \mathrm{kcal} \mathrm{mol}^{-1}\right.$, Figure 5, Table 3, entry 1$)$. Breaking and forming bonds in dashed lines, additional $\mathrm{C}-\mathrm{H}$-interactions with dotted lines (M06-2X-D3/6-311++G(d,p)(PCM=THF)//B3LYP-D3BJ/6-31G(d) at $298 \mathrm{~K})$. dotted lines in $\mathrm{TS}_{\text {front2 }} 7$, Figure 7, five dotted lines in $\mathrm{TS}_{\text {front } 1}$ 7, Figure 6).

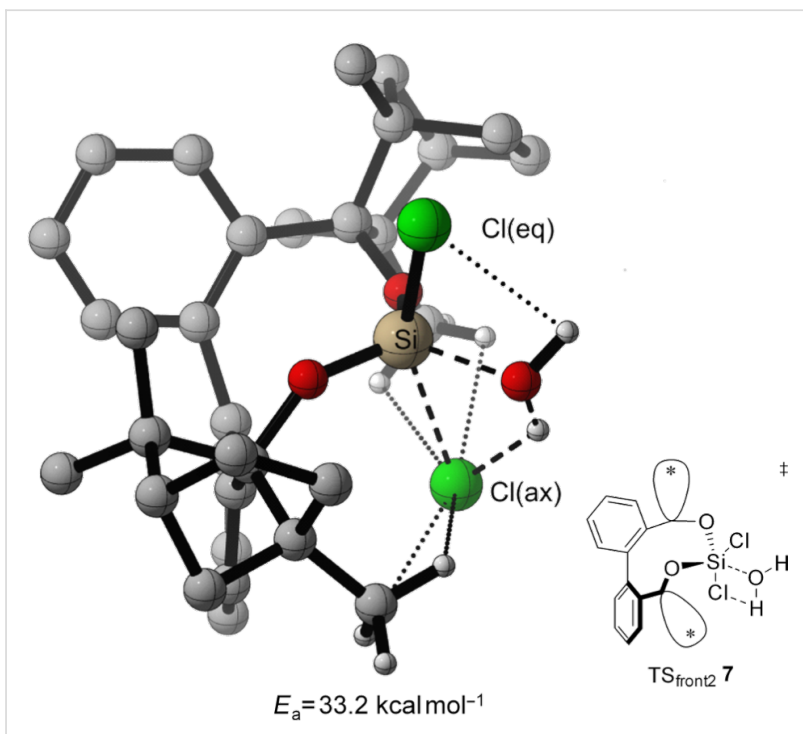

Figure 7: Transition state leading to $\mathbf{8}_{\mathrm{ax}}$ following front2 attack $\left(E_{\mathrm{a}}=33.2 \mathrm{kcal} \mathrm{mol}^{-1}\right.$, Figure 5 , Table 3 , entry 2$)$. Breaking and forming bonds in dashed lines, additional $\mathrm{C}-\mathrm{H}$-interactions with dotted lines (M06-2X-D3/6-311++G(d,p)(PCM=THF)//B3LYP-D3BJ/6-31G(d) at $298 \mathrm{~K})$.

Through the approach of the attacking water molecule in the side attack mechanism, the chloro atoms are forced to get closer to each other leading to electrostatic repulsion (Figure 8). Stabilizing $\mathrm{C}-\mathrm{H}$ interaction from the fenchyl group to the exiting chloride can be found as well (one dotted line in $\mathrm{TS}_{\text {side }} \mathbf{7 \text { , }}$ Figure 8).

At the second step, the side mechanism leads to a lower energy barrier $\left(\mathrm{TS}_{\text {side }} \mathbf{8}_{\mathbf{a x}} E_{\mathrm{a}}=31.4 \mathrm{kcal} \mathrm{mol}^{-1}\right.$, Table 3, entry 6 , Figure 9) than the front attack mechanisms $\left(\mathrm{TS}_{\text {front1 }} \mathbf{8}_{\mathbf{a x}}\right.$ $E_{\mathrm{a}}=33.4 \mathrm{kcal} \mathrm{mol}^{-1}, \mathrm{TS}_{\text {front2 }} \mathbf{8}_{\text {eq }} E_{\mathrm{a}}=40.2 \mathrm{kcal} \mathrm{mol}^{-1}$, Table 3, entries 4 and 5, Figure 10 and Figure 11). In the former mechanism the chloro atom comes closer to the already present hydroxy group (Figure 9).

A contact between the $\mathrm{OH}(\mathrm{ax})$ and the $\mathrm{Cl}(\mathrm{eq})$ is found, in addition to the $\mathrm{C}-\mathrm{H}$ interaction (dotted line, Figure 9), which stabilized the leaving $\mathrm{Cl}$ ion with a weak hydrogen bond. In the front attack mechanisms for the second hydrolytic step only stabilizing $\mathrm{C}-\mathrm{H}$ interactions from the fenchyl group to the chloro atom occur (dotted line, Figure 10 and Figure 11).

The highest energy barriers of the computed molecules are found for $\mathrm{BIFOXSiCl}_{2}$ for the first step $\left(E_{\mathrm{a}}=32.6 \mathrm{kcal} \mathrm{mol}^{-1}\right.$, $E_{\mathrm{a}}=33.2 \mathrm{kcal} \mathrm{mol}^{-1}, E_{\mathrm{a}}=37.3 \mathrm{kcal} \mathrm{mol}^{-1}$, Table 3 , entries $1-3$, Figures 6-8) and for $\mathrm{BIFOXSiCl}(\mathrm{OH})(8)$ for the second 


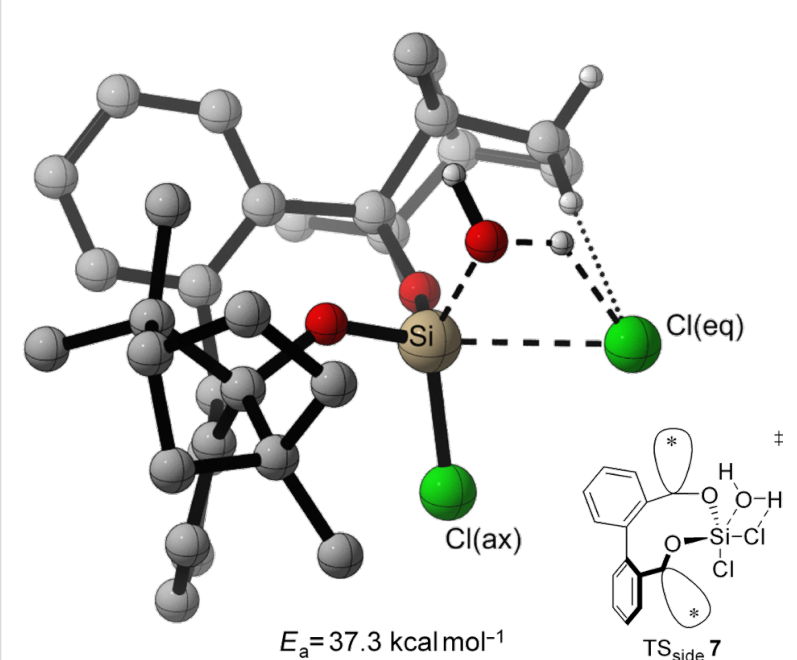

Figure 8: Transition state leading to $\mathbf{8}_{\text {eq }}$ following side attack $\left(E_{\mathrm{a}}=37.4 \mathrm{kcal} \mathrm{mol}^{-1}\right.$, Figure 5, Table 3 , entry 3$)$. Breaking and forming bonds in dashed lines, additional $\mathrm{C}-\mathrm{H}$-interactions with dotted lines (M06-2X-D3/6-311++G(d,p)(PCM=THF)//B3LYP-D3BJ/6-31G(d) at $298 \mathrm{~K})$.

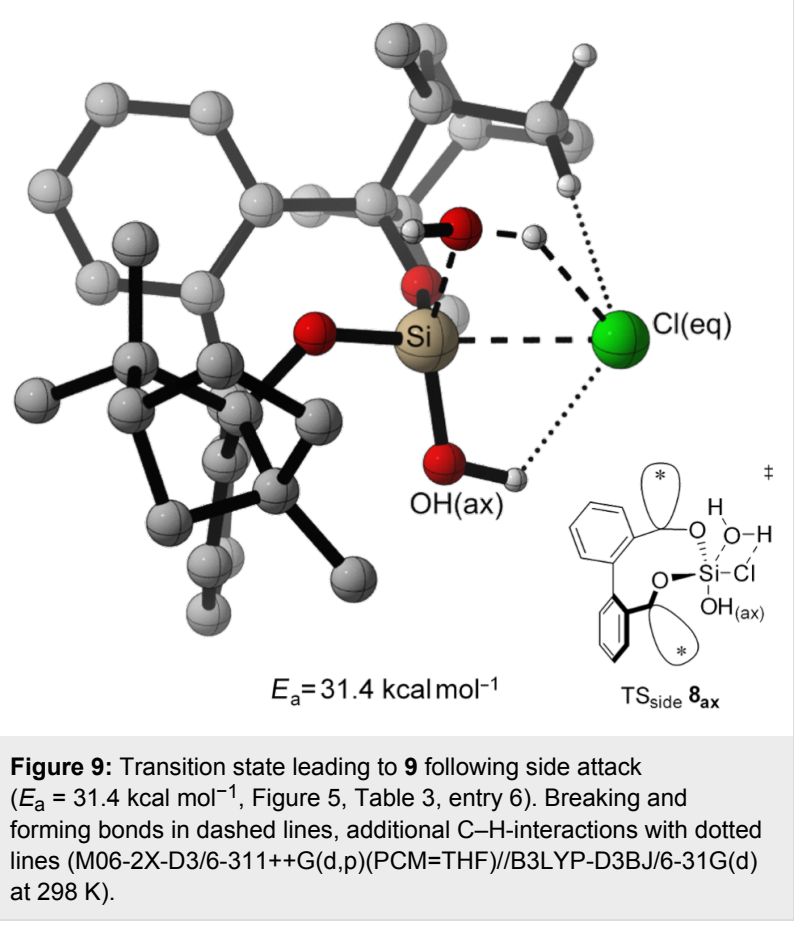

step $\left(E_{\mathrm{a}}=33.4 \mathrm{kcal} \mathrm{mol}^{-1}, E_{\mathrm{a}}=31.4 \mathrm{kcal} \mathrm{mol}^{-1}\right.$, $E_{\mathrm{a}}=40.2 \mathrm{kcal} \mathrm{mol}^{-1}$, Table 3, entries 4-6, Figures 9-11), which also confirms the kinetics study of $\mathrm{BIFOXSiCl}_{2}(7)$ and $\mathrm{BIFOXSiCl}(\mathrm{OH})(\mathbf{8})$ as the most stable dichlorosilane and chlorosilanol (Figure 2 and Figure 3, Table 2). In comparison the front attack mechanism for dichlorosilane $\mathbf{1 3}$ $\left(E_{\mathrm{a}}=27.7 \mathrm{kcal} \mathrm{mol}^{-1}\right.$, Table 3, entry 7$)$ has a lower energy barrier than side attack mechanism $\left(E_{\mathrm{a}}=35.4 \mathrm{kcal} \mathrm{mol}^{-1}\right.$,

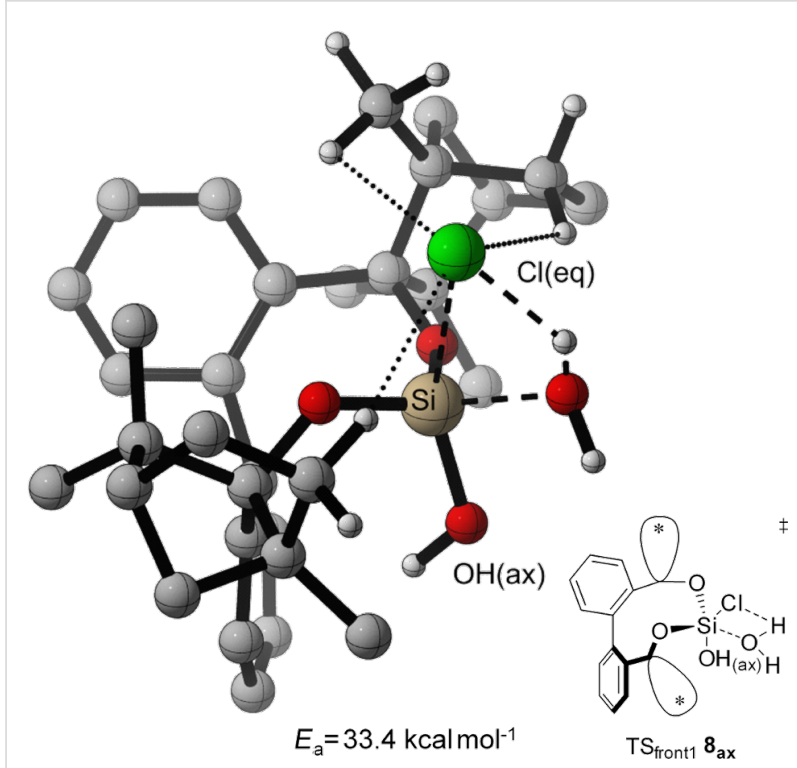

Figure 10: Transition state leading to 9 following front1 attack $\left(E_{\mathrm{a}}=33.4 \mathrm{kcal} \mathrm{mol}^{-1}\right.$, Figure 5, Table 3, entry 4). Breaking and forming bonds in dashed lines, additional $\mathrm{C}-\mathrm{H}$-interactions with dotted lines (M06-2X-D3/6-311++G(d,p)(PCM=THF)//B3LYP-D3BJ/6-31G(d) at $298 \mathrm{~K})$.

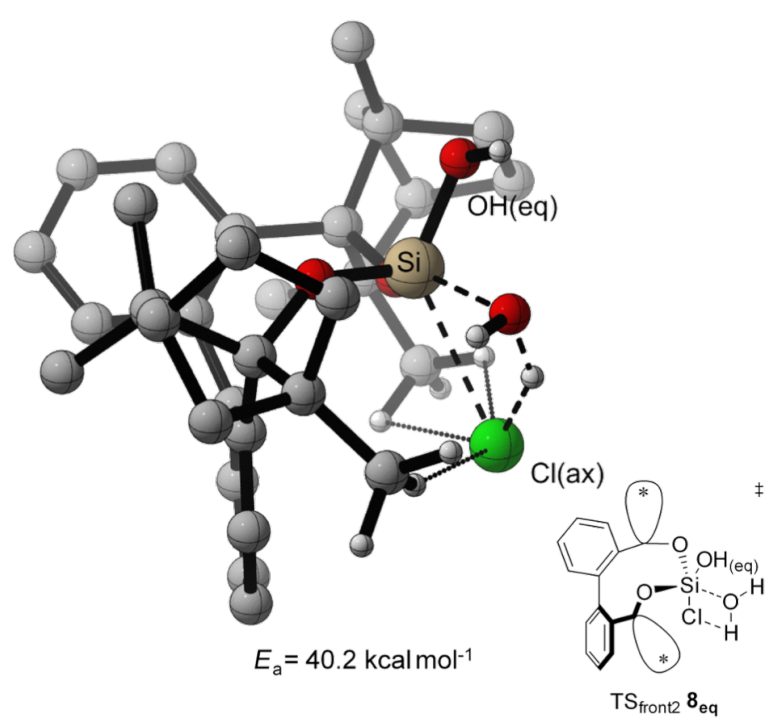

Figure 11: Transition state leading to 9 following front2 attack $\left(E_{\mathrm{a}}=40.2 \mathrm{kcal} \mathrm{mol}^{-1}\right.$, Figure 5, Table 3, entry 5). Breaking and forming bonds in dashed lines, additional $\mathrm{C}-\mathrm{H}$-interactions with dotted lines (M06-2X-D3/6-311++G(d,p)(PCM=THF)//B3LYP-D3BJ/6-31G(d) at $298 \mathrm{~K})$.

Table 3, entry 8 ). The second hydrolysis, $\mathbf{1 3}_{\mathbf{C l O H}}$ to $\mathbf{1}$ has a higher energy barrier $\left(E_{\mathrm{a}}=29.1 \mathrm{kcal} \mathrm{mol}^{-1}\right.$ for front attack mechanism (Table 3, entry 9) and $E_{\mathrm{a}}=29.9 \mathrm{kcal} \mathrm{mol}^{-1}$ for side attack mechanism (Table 3, entry 10)) than the first. In accordance with the kinetic study, dichlorosilane $\mathbf{1 3}$ hydrolysed 
faster than $\mathrm{BIFOXSiCl}_{2}$ (7, Scheme 4). In addition, the hydrolysis of glycol-based dichlorosilane (Table 3, entries 11 and 12) and tetrachlorosilane (Table 3, entries 13 to 16 ) is computed as model system. The first hydrolytic step of $\mathrm{SiCl}_{4}$ has a higher energy barrier $\left(E_{\mathrm{a}}=28.4 \mathrm{kcal} \mathrm{mol}^{-1}\right.$, Table 3, entry 13) than 13 to $\mathbf{1 3}_{\mathbf{C l O H}}\left(E_{\mathrm{a}}=27.7 \mathrm{kcal} \mathrm{mol}^{-1}\right.$, Table 3 , entry 7$)$ and $\mathbf{1 3}_{\mathbf{C l O H}}$ to $1\left(E_{\mathrm{a}}=29.1 \mathrm{kcal} \mathrm{mol}^{-1}\right.$, Table 3 , entry 9$)$. The glycol-substituted dichlorosilane has a smaller energy barrier to the TS $\left(E_{\mathrm{a}}=23.6 \mathrm{kcal} \mathrm{mol}^{-1}\right.$, Table 3 , entry 11 , Figure 5 and $E_{\mathrm{a}}=21.1 \mathrm{kcal} \mathrm{mol}^{-1}$, Table 3, entry 12, Figure 5). The stepwise hydrolysis of tetrachlorosilane shows that the energy barrier for the first step is higher $\left(E_{\mathrm{a}}=28.4 \mathrm{kcal} \mathrm{mol}^{-1}\right.$, Table 3 , entry 13$)$, than the second step $\left(E_{\mathrm{a}}=25.0 \mathrm{kcal} \mathrm{mol}^{-1}\right.$, Table 3 , entry 14). With two hydroxy substituents, the energy barrier for the third TS is $E_{\mathrm{a}}=20.9 \mathrm{kcal} \mathrm{mol}^{-1}$ (Table 3, entry 15) and for the fourth step $\left(E_{\mathrm{a}}=20.8 \mathrm{kcal} \mathrm{mol}^{-1}\right.$, Table 3, entry 16). For the computed values, it should be noted that THF is used for the PCM solvent correction, but the reactions are carried out in a $1 / 1$ mixture of water/THF.
A hydrogen bridge is a displacement of electrons (lp or $\pi$ ) from a donor into the $\sigma^{*}$ orbital of an $\mathrm{H}-\mathrm{X}$ bond. NBO analyses can be used to calculate the energy of such an interaction. With the shift of the electron density of a lone pair into the $\sigma^{*}$ orbital, the $\mathrm{O}-\mathrm{H}$ bond of the HB donor is weakened. This causes a change in the $\mathrm{O}-\mathrm{H}$ stretching frequency of the bond. A strong hydrogen bridge results from strong lone pair $\cdots \sigma^{*}$ orbital interactions, resulting in a weakening of the $\mathrm{O}-\mathrm{H}$ bond, which in turn results in a decrease of the $\mathrm{O}-\mathrm{H}$ stretching frequency [71]. An alternative method is to determine the relaxed force constant [72]. In the following, the stretching frequency und the NBO analyses were calculated for different acceptors and water (Table 4).

The silanol group is a better hydrogen bond acceptor than an alcohol group for single hydrogen bonds $\left(\mathrm{CH}_{3} \mathrm{OH}\right.$ (11.88 kcal mol$\left.{ }^{-1}\right)$ vs $\mathrm{SiH}_{3} \mathrm{OH}\left(16.43 \mathrm{kcal} \mathrm{mol}^{-1}\right)$, Table 4, entries 1 and 2), which is more acidic and inconsistent with the results of West et al. [73]. In case of double hydrogen bonds in

\begin{tabular}{|c|c|c|c|c|}
\hline entry & & $\begin{array}{l}\mathrm{V}_{\mathrm{O}-\mathrm{H}} \\
{\left[\mathrm{cm}^{-1}\right]}\end{array}$ & $\begin{array}{l}\text { lp- } \sigma^{*} \text { energy } \\
{\left[\mathrm{kcal} \mathrm{mol}^{-1}\right]}\end{array}$ & $\begin{array}{l}\mathrm{D} O \cdots X \\
{[\AA]}\end{array}$ \\
\hline 1 & $\mathrm{CH}_{3}-\mathrm{OH} \cdots \mathrm{OH}_{2}$ & 3741 & 11.88 & 2.785 \\
\hline 2 & $\mathrm{SiH}_{3}-\mathrm{OH} \cdots \mathrm{OH}_{2}$ & 3602 & 16.43 & 2.793 \\
\hline 3 & $\begin{array}{l}\mathrm{Si}(\mathrm{OH})_{3}-\mathrm{OH} \cdots \mathrm{OH}_{2} \\
\mathrm{H}_{2} \mathrm{O} \cdots \mathrm{OH}-\mathrm{Si}(\mathrm{OH})_{3}\end{array}$ & $\begin{array}{l}3441 \\
3608\end{array}$ & $\begin{array}{l}20.39 \\
12.05\end{array}$ & $\begin{array}{l}2.732 \\
2.797\end{array}$ \\
\hline 4 & $\begin{array}{l}\mathrm{SiCl}(\mathrm{OH})_{2}-\mathrm{OH} \cdots \mathrm{OH}_{2} \\
\mathrm{H}_{2} \mathrm{O} \cdots \mathrm{OH}-\mathrm{SiCl}(\mathrm{OH})_{2}\end{array}$ & $\begin{array}{l}3450 \\
3649\end{array}$ & $\begin{array}{l}19.44 \\
7.78\end{array}$ & $\begin{array}{l}2.727 \\
2.862\end{array}$ \\
\hline 5 & $\begin{array}{l}\mathrm{SiCl}(\mathrm{OH})_{2}-\mathrm{OH} \cdots \mathrm{OH}_{2} \\
\mathrm{SiCl}(\mathrm{OH})_{2}-\mathrm{OH} \cdots \mathrm{OH}_{2} \\
\mathrm{H}_{2} \mathrm{O} \cdots \mathrm{Cl}-\mathrm{Si}(\mathrm{OH})_{3}\end{array}$ & $\begin{array}{l}3725 \\
3701 \\
3832\end{array}$ & $\begin{array}{l}6.78 \\
6.82 \\
1.58\end{array}$ & $\begin{array}{l}2.865 \\
2.863 \\
2.804\end{array}$ \\
\hline 6 & $\left(\mathrm{CH}_{2}\right)_{2} \mathrm{O}_{2} \mathrm{Si}-(\mathrm{OH})_{2} \cdots \mathrm{OH}_{2}$ & $\begin{array}{l}3745^{\mathrm{b}} \\
3717^{\mathrm{b}} \\
3691^{\mathrm{c}}\end{array}$ & $\begin{array}{l}7.62 \\
7.59\end{array}$ & $\begin{array}{l}2.855 \\
2.857\end{array}$ \\
\hline 7 & $\begin{array}{l}\left(\mathrm{CH}_{2}\right)_{2} \mathrm{O}_{2} \mathrm{SiCl}-\mathrm{OH} \cdots \mathrm{OH}_{2} \\
\mathrm{H}_{2} \mathrm{O} \cdots \mathrm{Cl}-\mathrm{Si}(\mathrm{OH}) \mathrm{O}_{2}\left(\mathrm{CH}_{2}\right)_{2}\end{array}$ & $\begin{array}{l}3377 \\
3819^{c} \\
3707^{b}\end{array}$ & $\begin{array}{l}22.16 \\
1.58\end{array}$ & $\begin{array}{l}2.705 \\
3.331\end{array}$ \\
\hline 8 & $\begin{array}{l}\left(\mathrm{CH}_{2}\right)_{2} \mathrm{O}_{2} \mathrm{C}-(\mathrm{OH})_{2} \cdots \mathrm{OH}_{2} \\
\left(\mathrm{CH}_{2}\right)_{2} \mathrm{O}_{2} \mathrm{C}-(\mathrm{OH})_{2} \cdots \mathrm{OH}_{2} \\
\mathrm{H}_{2} \mathrm{O} \cdots \mathrm{O}_{2}\left(\mathrm{CH}_{2}\right)_{2} \mathrm{C}(\mathrm{OH})_{2}\end{array}$ & $\begin{array}{l}3678^{c} \\
3631^{c} \\
3604^{c}\end{array}$ & $\begin{array}{l}6.57 \\
8.69 \\
8.96\end{array}$ & $\begin{array}{l}2.844 \\
2.816 \\
2.715\end{array}$ \\
\hline 9 & $\begin{array}{l}\text { BIFOXSiCl-OH } \cdots \mathrm{OH}_{2} \\
\text { BIFOXSi(OH)-Cl } \cdots \mathrm{H}_{2} \mathrm{O}\end{array}$ & $\begin{array}{l}3445 \\
3691^{b} \\
3811^{c}\end{array}$ & $\begin{array}{l}24.90 \\
5.19\end{array}$ & $\begin{array}{l}2.734 \\
3.273\end{array}$ \\
\hline 10 & $\operatorname{BIFOXSi}(\mathrm{OH})_{2} \cdots \mathrm{OH}_{2}$ & $\begin{array}{l}3733^{b} \\
3703^{c} \\
3685^{c}\end{array}$ & $\begin{array}{l}9.73 \\
10.15\end{array}$ & $\begin{array}{l}2.878 \\
2.834\end{array}$ \\
\hline 11 & BIFOXSiCl-OH $\cdots \mathrm{Cl}^{-}$ & 3165 & 36.87 & 2.994 \\
\hline 12 & $\mathrm{BIFOXSi(OH})_{2} \cdots \mathrm{Cl}^{-}$ & $\begin{array}{l}3421 \\
3151\end{array}$ & $\begin{array}{l}17.36 \\
33.61\end{array}$ & $\begin{array}{l}3.082 \\
2.927\end{array}$ \\
\hline 13 & $\operatorname{BIFOXSi(OH})_{2}-$ dimer & $\begin{array}{l}3670 \\
3490\end{array}$ & $\begin{array}{l}7.55 \\
21.63\end{array}$ & $\begin{array}{l}2.880 \\
2.752\end{array}$ \\
\hline
\end{tabular}

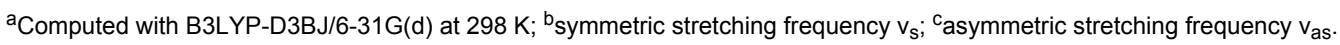


the glyoxal based system, both are equally strong, because of a third hydrogen bond, a rebond from where water is the acceptor and the oxygen in the ring is the donor $\left(\left(\mathrm{CH}_{2}\right)_{2} \mathrm{O}_{2} \mathrm{Si}(\mathrm{OH})_{2}\right.$ $\left(15.21 \mathrm{kcal} \mathrm{mol}^{-1}\right)$ vs $\left(\mathrm{CH}_{2}\right)_{2} \mathrm{O}_{2} \mathrm{C}(\mathrm{OH})_{2}\left(15.26 \mathrm{kcal} \mathrm{mol}^{-1}\right)$, Table 4, entries 6 and 8), Two possible geometries can be observed for $\mathrm{SiCl}(\mathrm{OH})_{3}$. On the one hand with two hydrogen bridges to water (13.60 $\mathrm{kcal} \mathrm{mol}^{-1}$, Table 4, entry 5) or with one hydrogen bridge to water $\left(19.44 \mathrm{kcal} \mathrm{mol}^{-1}\right.$, Table 4 , entry 4), with an additional rebond of the oxygen of one of the $\mathrm{SiOH}$ groups to water $\mathrm{H}-\mathrm{O}\left(7.78 \mathrm{kcal} \mathrm{mol}^{-1}\right.$, Table 4, entry 4). The trend of the stronger single hydrogen bridge compared to the double hydrogen bridge is also reflected in the systems glycolic (22.16 kcal mol ${ }^{-1}$ vs $15.21 \mathrm{kcal} \mathrm{mol}^{-1}$, Table 4, entries 6 and 7) and BIFOSi $\left(24.90 \mathrm{kcal} \mathrm{mol}^{-1}\right.$ vs $19.88 \mathrm{kcal} \mathrm{mol}^{-1}$, Table 4, entries 9 and 10). As was to be expected, the energies of the $\mathrm{O}-\mathrm{H}$ bonds decreases with increasing lone pair $\cdots \sigma^{*}$ orbital interactions $\left(3502 \mathrm{~cm}^{-1}\right.$ to $22.16 \mathrm{kcal} \mathrm{mol}^{-1} \mathrm{vs} 3830 \mathrm{~cm}^{-1}$ to $3.06 \mathrm{kcal} \mathrm{mol}^{-1}$, Table 4, entries 5 and 7). With a stronger electron donor, as the chloride ion, the lone pair ${ }^{\cdots} \sigma^{*}$ orbital interactions rises $\left(36.87 \mathrm{kcal} \mathrm{mol}^{-1}\right.$ vs $50.97 \mathrm{kcal} \mathrm{mol}^{-1}$, Table 4, entries 11 and 12). In here, the $\operatorname{BIFOXSi(OH})_{2}(9)$ binds the chlorid stronger with two hydrogen bridges, than BIFOXSiCl(OH) (8) with just one hydrogen bridge. The $\operatorname{BIFOXSi}(\mathrm{OH})_{2}(\mathbf{9})$ dimer forms hydrogen bridges, which are stronger than hydrogen bridges with water, but less stronger than hydrogen bridges to chloride $\left(50.97 \mathrm{kcal} \mathrm{mol}^{-1} \mathrm{vs}\right.$ $29.18 \mathrm{kcal} \mathrm{mol}^{-1}$ vs $19.88 \mathrm{kcal} \mathrm{mol}^{-1}$, Table 4, entries 13,12 , and 10).

\section{X-ray analyses}

Dichlorosilane 7 (Figure 12), as well as chlorosilanol 8 (Figure 13) crystallize as monomers from $n$-hexane. $\mathrm{BIFOXSiCl}(\mathrm{OH})(\mathbf{8})$ is obtained as the $\mathbf{8}_{\mathbf{a x}}$ isomer, which is computed to be the more stable isomer (Table 3, entry 1).

Since the commercially available $(+)$-fenchone has $98 \%$ enantiomeric purity, $\mathrm{BIFOXSi}(\mathrm{OH})_{2}$ can be further purified. racBIFOXSi $(\mathrm{OH})_{2}$ crystallizes as a dimer from toluene (Figure 14). BIFOXSi(OH) 2 (9) crystallizes as a tetramer from $n$-hexane (Figure 15), where six $\mathrm{OH}$ groups build a network of hydrogen bonds. Thus the polar core is shielded against the solvent (Figure 15). For silanediols 2a and $2 \mathbf{b}$ (Figure 1) dimeric structures are reported as well [41-44]. In these, hydrogen bond lengths of $1.86 \AA$ to $2.01 \AA(\mathrm{H} \cdots \mathrm{O})$ and $2.65-2.80 \AA(\mathrm{O}-\mathrm{H} \cdots \mathrm{O})$ are observed. Bond angles vary from $157.3^{\circ}$ to $174.3^{\circ}$ for the hydrogen bonds between the silanediols [41-44]. In the dimeric and tetrameric structure of $\operatorname{BIFOXSi}(\mathrm{OH})_{2}(\mathbf{9}$, Figure 14 and Figure 15) those distances are 1.82(4) $\AA$ to $2.02(4) \AA(\mathrm{H} \cdots \mathrm{O})$ and 2.66(4) $\AA$ to $2.79(5) \AA(\mathrm{O}-\mathrm{H} \cdots \mathrm{O})$ with angles between $152,4(6)^{\circ}$ and $172,0(7)^{\circ}$ (Table 5). These distances indicate medium strong hydrogen bonds [74].

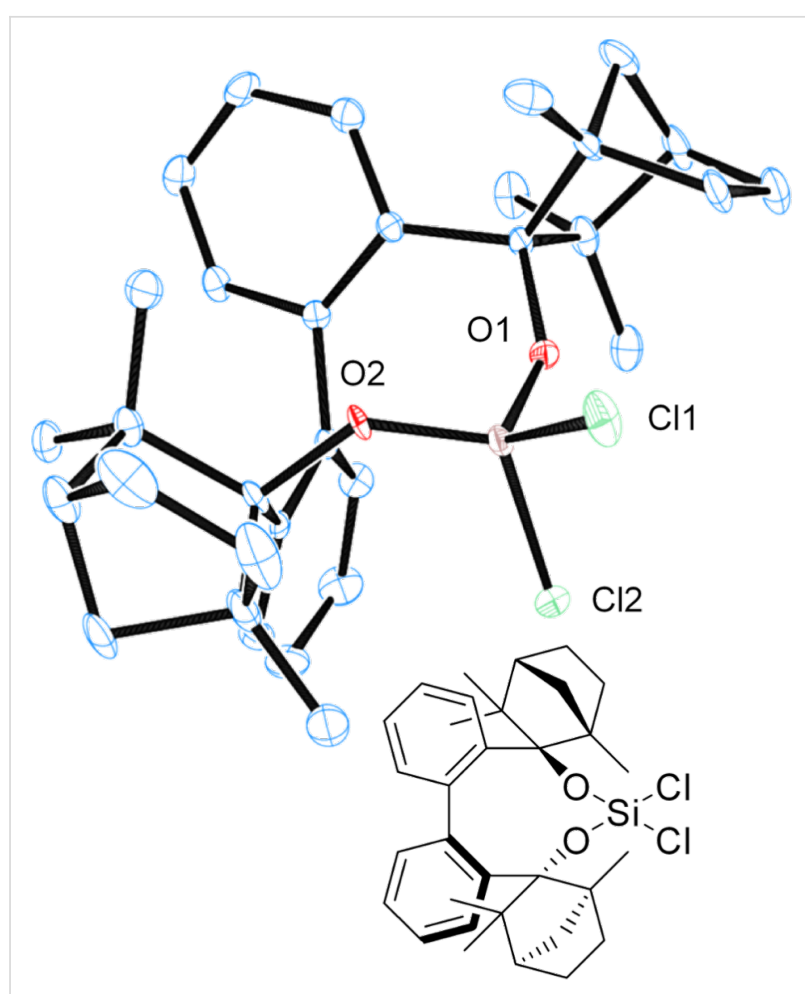

Figure 12: X-ray crystal structure of $\mathrm{BIFOXSiCl}_{2}(7) . \mathrm{H}$ atoms on the chiral backbone are omitted for clarity issues and the ellipsoids are shown with $65 \%$ probability.

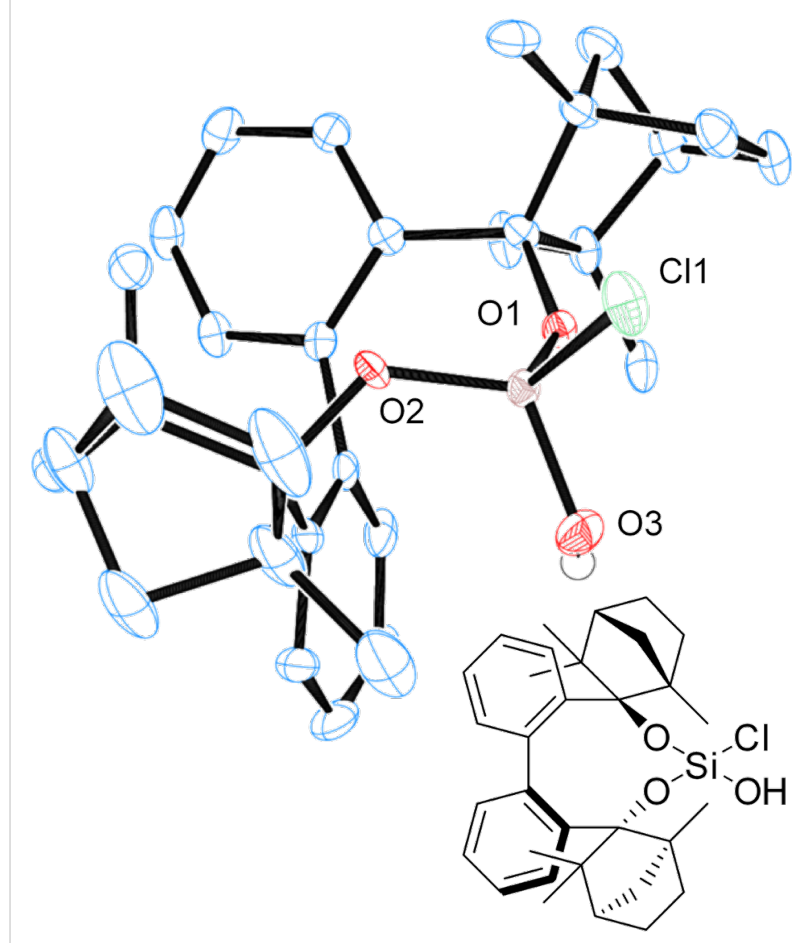

Figure 13: X-ray crystal structure of $\mathrm{BIFOXSiCl}(\mathrm{OH})(8) . \mathrm{H}$ atoms on the chiral backbone are omitted for clarity issues and the ellipsoids are shown with $65 \%$ probability. 


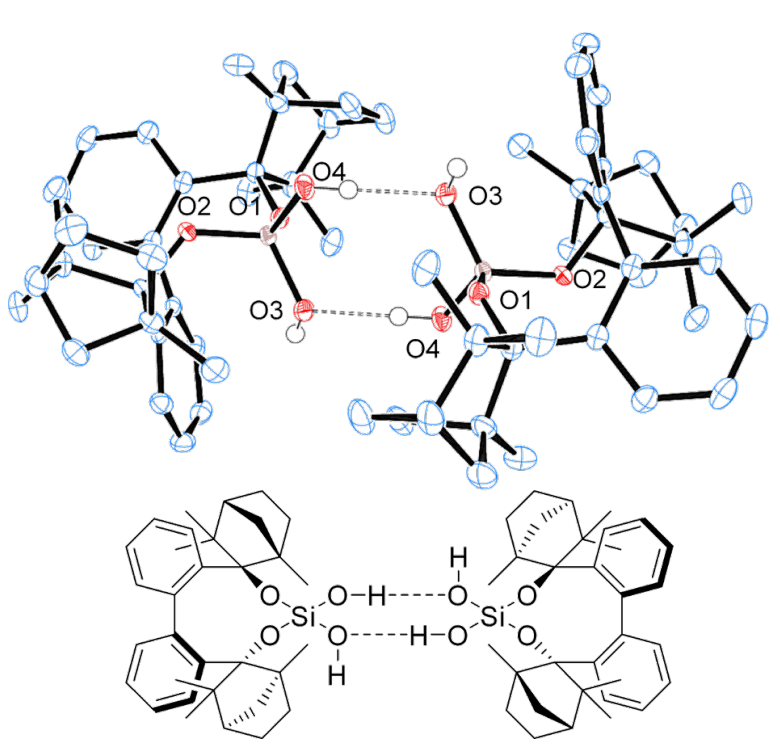

Figure 14: X-ray crystal structure ofrac-BIFOXSi(OH) $)_{2}$ (9) forming dimers. $\mathrm{H}$ atoms on the chiral backbone are omitted for clarity issues and the ellipsoids are shown with $65 \%$ probability. For bond lengths and angles see Table 5 .

X-ray structures of $\operatorname{BIFOXSi}(\mathrm{OH})_{2}(9$, Figure 16) and $\mathrm{BIFOXSiCl}(\mathrm{OH})(\mathbf{8}$, Figure 17) with co-crystallized acetone indicate the bonding behavior of the silanediols to carbonyl acceptors.
Chlorosilanol 8 binds one acetone with a bonding length of $2.16(0) \AA(\mathrm{H} 3 \cdots \mathrm{O} 4)$ and $2.89(4) \AA(\mathrm{O} 3-\mathrm{H} \cdots \mathrm{O} 4)$ (Table 5, Figure 17), which is the longest hydrogen bond for $\operatorname{BIFOXSiCl}(\mathrm{OH})(\mathbf{8})$ and $\operatorname{BIFOXSi}(\mathrm{OH})_{2}(\mathbf{9})$. In dimeric structures of silanediol 9 (Figure 14) the hydroxy group $\mathrm{O} 4 \mathrm{H}$ is a hydrogen bond donor to $\mathrm{O} 3$. The hydrogen atom of the $\mathrm{O}-\mathrm{H}$ group $(\mathrm{O} 3 \mathrm{H})$ is pointing outwards and can form a hydrogen bond to an additional molecule. For silanediols $\mathbf{2 a}$ and $\mathbf{2 b}$ Franz et al. observed hydrogen bond distances of $1.88 \AA(\mathrm{H} \cdots \mathrm{O})$ and $2.68 \AA(\mathrm{O}-\mathrm{H} \cdots \mathrm{O})$ on average to guest molecules [41-44]. $\operatorname{BIFOXSi}(\mathrm{OH})_{2}(9$, Figure 16) binds an acetone in a similar manner $\left(\mathrm{O} 4{ }^{\prime}-\mathrm{H} \cdots \mathrm{O} 4-\mathrm{H} \cdots \mathrm{O} 6=\mathrm{C}\left(\mathrm{CH}_{3}\right)_{2}\right)$ with distances of $1.88(3) \AA(\mathrm{H} 4 \cdots \mathrm{O} 6)$ and $2.62(1) \AA(\mathrm{O} 4-\mathrm{H} \cdots \mathrm{O} 6)$ as well as $2.05(2) \AA\left(\mathrm{H} 4 \cdots \mathrm{O} 4{ }^{\prime}\right)$ and 2.73(1) $\AA\left(\mathrm{O} 4-\mathrm{H}^{\prime} \cdots \mathrm{O} 4\right.$ ') between the hydroxy groups. The second acetone is bonded with one hydroxy group of each of the $\operatorname{BIFOXSi}(\mathrm{OH})_{2}(9)$ with longer distances of 2.03(0) $\AA(\mathrm{H} \cdots \mathrm{O})$ and $2.80(3) \AA(\mathrm{O}-\mathrm{H} \cdots \mathrm{O})$ (Table 5). Similarly to the previously reported silanediol derivatives $\mathbf{2 a}$ and $\mathbf{2 b}$ [43], an increase of acidity of one outward facing $\mathrm{OH}$ group is achieved by intermolecular hydrogen bonds [43].

\section{Chloride binding}

The X-ray crystal structures of chlorosilanol 8 (Figure 17) and silanediol 9 (Figure 16) with co-crystallized acetone indicate the ability of binding ions or molecules via hydrogen bonds. To in-

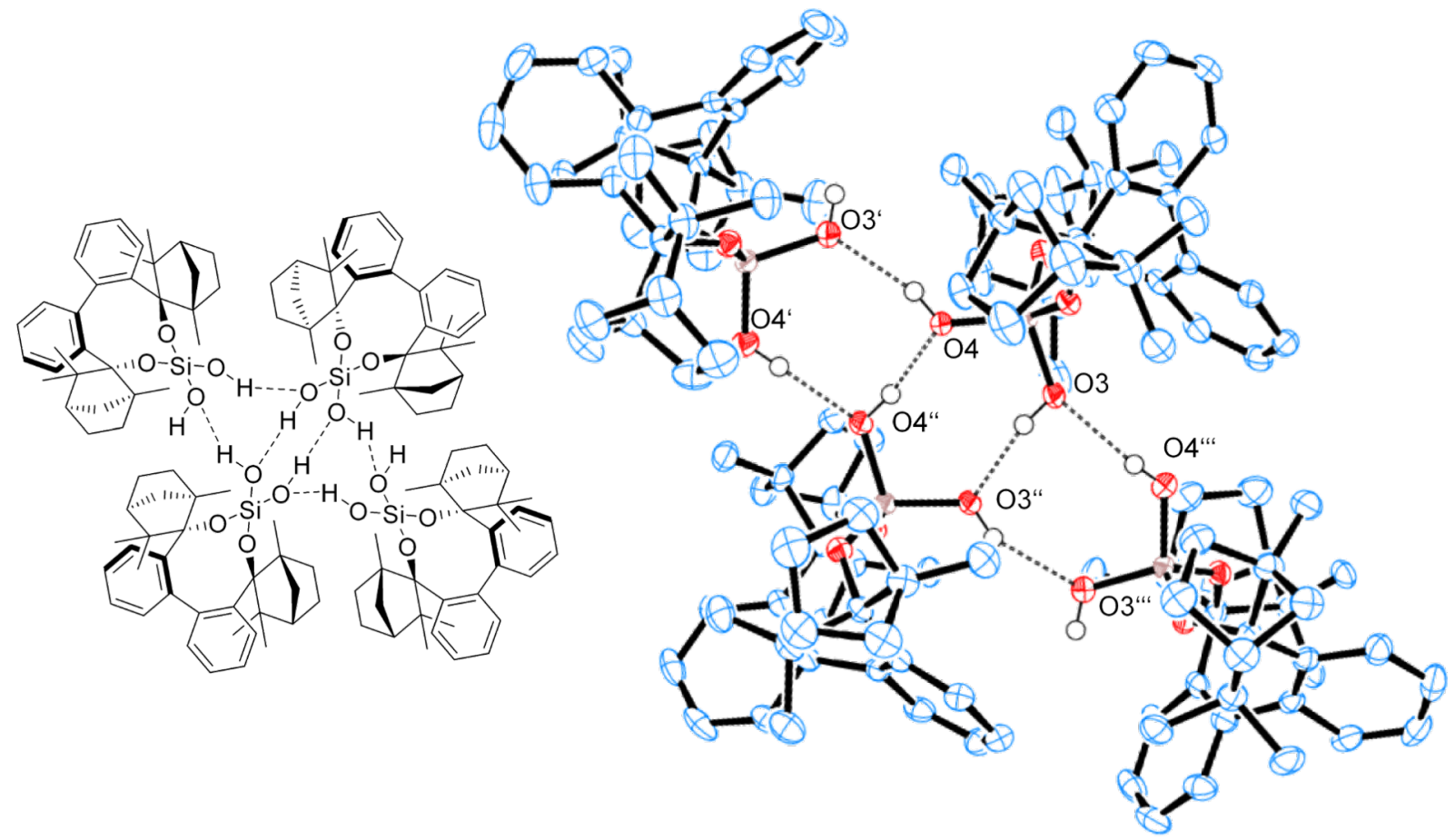

Figure 15: X-ray crystal structure of BIFOXSi $(\mathrm{OH})_{2}(9)$ forming a tetramer. $\mathrm{H}$ atoms on the chiral backbone are omitted for clarity issues and the ellipsoids are shown with $65 \%$ probability. For bond lengths and angles see Table 5 . 
Table 5: Bond lengths and angles of hydrogen bonds in X-ray crystal structures of $\mathrm{BIFOXSiCl(OH)}(\mathbf{8})$ and $\mathrm{BIFOXSi(OH})_{2}(\mathbf{9})$

\begin{tabular}{|c|c|c|c|c|}
\hline & $\mathrm{D}-\mathrm{H} \cdots \mathrm{A}$ & $D(D \cdots A)^{a}[\AA]$ & $\mathrm{D}(\mathrm{H} \cdots \mathrm{A})^{\mathrm{b}}[\AA]$ & $\Varangle(D-H \cdots A)\left[{ }^{\circ}\right]$ \\
\hline $\begin{array}{l}\mathrm{BIFOXSi(OH})_{2}(9) \\
\text { (Figure 14) }\end{array}$ & $\mathrm{O} 4 \mathrm{H}-\mathrm{O} 3$ & $2.76(1)$ & $1.92(0)$ & $170.0(5)$ \\
\hline $\begin{array}{l}\mathrm{BIFOXSi(OH})_{2}(\mathbf{9}) \\
\text { (Figure 15) }\end{array}$ & 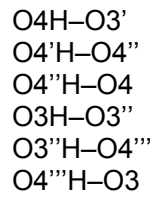 & $\begin{array}{l}2.76(2) \\
2.73(5) \\
2.66(4) \\
2.68(3) \\
2.79(9) \\
2.74(7)\end{array}$ & $\begin{array}{l}1.98(0) \\
1.95(0) \\
1.82(4) \\
1.85(8) \\
2.02(1) \\
2.02(4)\end{array}$ & $\begin{array}{l}163.7(4) \\
172.0(7) \\
165.5(0) \\
168.9(8) \\
152.4(6) \\
165.9(3)\end{array}$ \\
\hline $\begin{array}{l}\mathrm{BIFOXSi(OH})_{2}(\mathbf{9}) \\
\text { (Figure 16) }\end{array}$ & $\begin{array}{l}\mathrm{O} 3 \mathrm{H}-\mathrm{O} 5 \\
\text { O4H-O4' } \\
\text { O4H-O6 }\end{array}$ & $\begin{array}{l}2.80(3) \\
2.73(1) \\
2.62(1)\end{array}$ & $\begin{array}{l}2.03(0) \\
2.05(2) \\
1.88(3)\end{array}$ & $\begin{array}{l}161.1(8) \\
176.2(8) \\
146.3(6)\end{array}$ \\
\hline $\begin{array}{l}\text { BIFOXSiCl(OH) (8) } \\
\text { (Figure 17) }\end{array}$ & $\mathrm{O} 3 \mathrm{H}-\mathrm{O} 4$ & $2.89(4)$ & $2.16(0)$ & $167.1(8)$ \\
\hline
\end{tabular}

aDistance for hydrogen bond donor $(D)$ to hydrogen bond acceptor $(A)$. ${ }^{b}$ Distance for hydrogen $(H)$ to hydrogen bond acceptor $(A)$.

vestigate this ability, UV-vis titration experiments with tetrabutylammonium chloride (TBA-Cl) are carried out, with silanediol 1 as a reference (Table 6) [47,75]. For BIFOXSi(OH) $2(\mathbf{9}$, Figure 14, Figure 15) a binding constant of $5274.9 \mathrm{M}^{-1}(13 \%)$ for chloride is determined, which is in the same order as $\operatorname{di}(1-$ naphthyl)silanediol (1, Figure 1) with $4688.0 \mathrm{M}^{-1}$ (5\%, Table 6). The binding constant of chlorosilanol 8 (Figure 13) for chloride is $451.1 \mathrm{M}^{-1}(4 \%)$. Thus chlorosilanol 8 and silanediol 9 are feasible for anion binding of chloride.

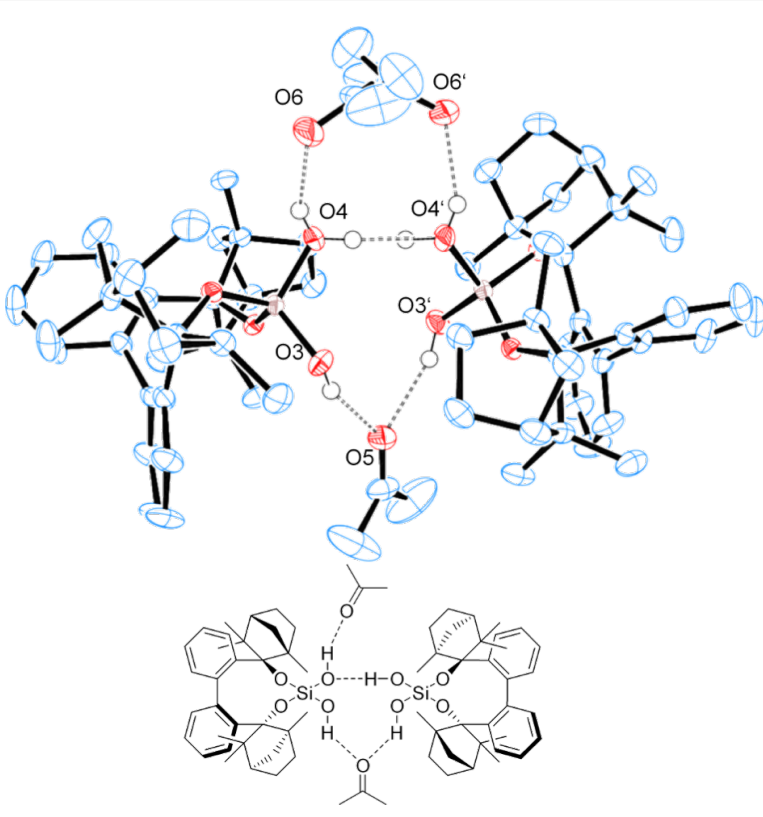

Figure 16: X-ray crystal structure of $\operatorname{BIFOXSi}(\mathrm{OH})_{2}(9)$ forming a dimeric structure with two bridged acetone molecules. $\mathrm{H}$ atoms on the chiral backbone are omitted for clarity issues. The acetone on the upper side is disordered by $50 \%$. Ellipsoids are shown with $65 \%$ probability. For bond lengths and angles see Table 5 .

\section{Counter ion catalyses}

The $N$-acyl Mannich reaction of isochinolin (16), which is activated with 2,2,2-trichloroethoxycarbonyl chloride (17, TrocCl) to carbamate 10, and different silyl ketene acetals $\mathbf{1 1 a - d}$

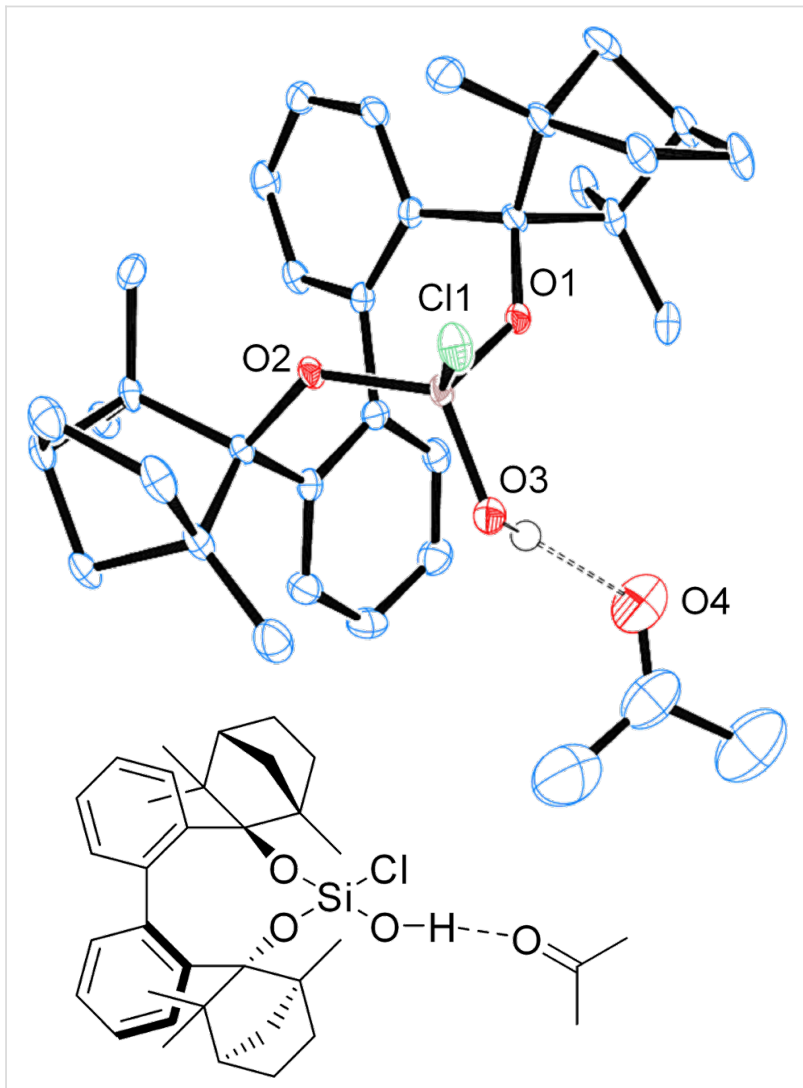

Figure 17: X-ray crystal structure of $\mathrm{BIFOXSiCl}(\mathrm{OH})(8)$, binding an acetone molecule. $\mathrm{H}$ atoms on the chiral backbone are omitted for clarity issues and the ellipsoids are shown with $65 \%$ probability. For bond lengths and angles see Table 5 . 
Table 6: Chloride binding constants $\left(K\left[\mathrm{M}^{-1}\right]\right.$, error $\left.(\%)\right)$ to BIFOXSiCl(OH) (8), BIFOXSi $(\mathrm{OH})_{2}(9)$ and di(1-naphthyl)silanediol (1) in $\mathrm{HCCl}_{3}$ at $22^{\circ} \mathrm{C}$ [75].

$$
8
$$$$
9
$$$$
1
$$

binding constant ${ }^{\mathrm{a}} \quad 451.1(4 \%) \quad 5274.9(13 \%) \quad 4688.0(5 \%)$

aCalculated for 1:1 binding mode between chloride and hydrogen bond donor [75].

yielding product 12 (Scheme 6) [45,47], is studied. Mattson et al. proposed a mechanism where the chloride ion is abstracted from 10 and binds via hydrogen bonding to the catalyst (Scheme 6) $[45,47]$. This leads to an ion pair $[\mathrm{cat} \cdot \mathrm{Cl}]^{-}$and [isoquinolinium cation] $^{+}$(Scheme 6). The nucleophilic silyl ketene acetal reacts with the [isoquinolinium cation] ${ }^{+}$and forms the $\mathrm{C}-\mathrm{C}$ bond, yielding product 12 (Scheme 6).

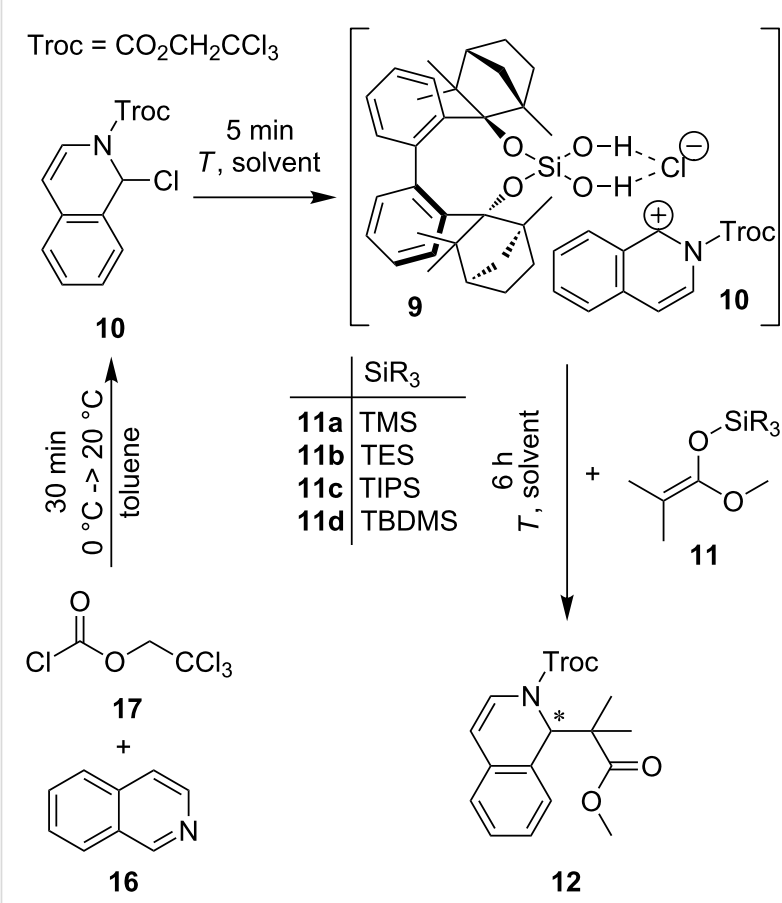

Scheme 6: Hydrogen-bond-catalyzed $\mathrm{N}$-acyl Mannich reaction of in situ-generated 10 with different silyl ketene acetals 11 a-d and BIFOXSi $(\mathrm{OH})_{2}(9)$ yielding $\mathrm{C}-\mathrm{C}$ coupling product 12 (Tables $6-8$ ); (TMS: trimethylsilane. TES: triethylsilane. TIPS: triisopropylsilane. TBDMS: tert-butyldimethylsilane).

The reactivity and stability of such an ion pair depend on the employed solvent. For this reaction and $\operatorname{BIFOXSi}(\mathrm{OH})_{2}(9)$ as catalyst, several solvents are tested (Table 7). In a nonpolar solvent like $n$-hexane, no catalytic activity is observed (Table 7 , entry 1). In halogenated solvents as dichloromethane (DCM) and 1,2-dichloroethane (1,2-DCE) the reaction takes place but without any enantiomeric excess (ee) (Table 7, entries 2 and 3).
In DCM the highest yield is isolated, but that is due to a fast background reaction [45]. With toluene as solvent, no background reaction is observed (Table 9, entry 9). To stabilize and improve the ion pair, polar solvents are tested as diethyl ether and dimethylformamide gave no conversion and starting material is obtained (Table 7, entries 4 and 5), acetonitrile and acetone increase the yield (Table 7, entries 6 and 7), but without any enantiomeric excess. In toluene, $\operatorname{BIFOXSi}(\mathrm{OH})_{2}(9)$, forms $43 \%$ yield at $-80{ }^{\circ} \mathrm{C}$ and $5 \%$ ee (Table 7 , entry 8 ). At higher temperature, 12 is isolated with $52 \%$ yield and $12 \%$ ee $\left(-60{ }^{\circ} \mathrm{C}\right.$, Table 7, entry 9). Further aromatic solvents are tested (Table 7 , entries 10-13), but without any improvement in yield or ee.

\begin{tabular}{|c|c|c|c|c|}
\hline entry & solvent & $T\left[{ }^{\circ} \mathrm{C}\right]$ & yield [\%] ${ }^{\mathrm{b}}$ & ee $[\%]^{c}$ \\
\hline 1 & $n$-hexane & -60 & 0 & - \\
\hline 2 & $\mathrm{DCM}$ & -60 & 87 & 0 \\
\hline 3 & 1.2-DCE & -30 & 33 & 0 \\
\hline 4 & diethyl ether & -60 & 0 & - \\
\hline 5 & dimethylformamide & -40 & 0 & - \\
\hline 6 & acetonitrile & -40 & 35 & 1 \\
\hline 7 & acetone & -80 & 10 & 0 \\
\hline 8 & toluene & -80 & 43 & 5 \\
\hline 9 & toluene & -60 & 52 & 12 \\
\hline 10 & benzene & rt & 10 & 1 \\
\hline 11 & $m$-xylene & -60 & $<1$ & 12 \\
\hline 12 & nitrobenzene & rt & 40 & 0 \\
\hline 13 & pyridine & -30 & 0 & - \\
\hline
\end{tabular}

a Reactions carried out with $20 \mathrm{~mol} \% 9,0.1 \mathrm{mmol} 16,0.11 \mathrm{mmol} 17$ and $0.15 \mathrm{mmol} 11 \mathrm{c}$ in $4 \mathrm{~mL}$ solvent; $\mathrm{b}_{\text {isolated yields; }{ }^{\mathrm{C}} \text { chiral }}$ HPLC OD-H, $n$-hexane/iPrOH 90:10, $1 \mathrm{~mL} / \mathrm{min}, 220 \mathrm{~nm}, 25^{\circ} \mathrm{C},(-)-12$ correlates to $(S)-12[45,76]$.

Variation of the catalyst loading suggests a ratio of $10 \mathrm{~mol} \%$ of $\operatorname{BIFOXSi}(\mathrm{OH})_{2}(9$, Table 8, entries 1-4) to be optimal. An increase of temperature results in decreasing yields and ee (Table 8, entries 5-8). The highest ee is found with $20 \mathrm{~mol} \%$ catalyst ( $12 \%$ ee, $52 \%$ yield, Table 7 , entry 9 ).

$\operatorname{BIFOXSi}(\mathrm{OH})_{2}(\mathbf{9})$ performs better than $\mathrm{BIFOXSiCl}(\mathrm{OH})(\mathbf{8})$ which is in accordance with the determined binding constant for chloride (Table 6, Table 9). With $\operatorname{BIFOXSiCl}(\mathrm{OH})(8)$ a yield up to $60 \%$ is isolated (Table 9 , entry 3 ), but as racemate. $\mathrm{BIFOXSi}(\mathrm{OH})_{2}(9)$ catalyses the reaction with good yields up to $73 \%$ and an ee value of $12 \%$ (Table 9 , entry 7 ). For $11 \mathbf{a}, \mathbf{b}$ and d and silanediol $\mathbf{9}$ as catalyst, an enantiomeric inversion is observed (Table 9, entries 5, 6 and 8).

The substrate scope is broadened with 1-chloroisochroman (18) as alternative substrate (Table 10). The reaction mechanism is 
Table 8: Different catalyst loadings of BIFOXSi(OH) $)_{2}(9)$ and different temperatures in the $\mathrm{N}$-acyl Mannich reaction of 10 and 11c yielding product 12 (Scheme 6$)^{a}$.

\begin{tabular}{lllll} 
entry & cat loading $[\mathrm{mol} \%]$ & $T\left[{ }^{\circ} \mathrm{C}\right]$ & yield [\%] & ee [\%] \\
\hline 1 & 20 & -80 & 43 & 5 \\
2 & 10 & -80 & 52 & 7 \\
3 & 5 & -80 & 12 & 0 \\
4 & 1 & -80 & 2 & 2 \\
5 & 10 & -60 & 37 & 5 \\
6 & 10 & -40 & 18 & 7 \\
7 & 10 & 0 & 9 & 1 \\
8 & 10 & rt & 20 & 0
\end{tabular}

aReactions carried out with $0.1 \mathrm{mmol} 16,0.11 \mathrm{mmol} 17$ and $0.15 \mathrm{mmol}$ $11 \mathrm{c}$ in $4 \mathrm{~mL}$ toluene; bisolated yields, "chiral HPLC OD-H, $n$-hexane/ iPrOH 90:10, $1 \mathrm{~mL} / \mathrm{min}, 220 \mathrm{~nm}, 25^{\circ} \mathrm{C},(-)-12$ correlates to $(S)-12$ $[45,76]$.

Table 9: Performance of catalyst 8 and 9 in the $\mathrm{N}$-acyl Mannich reaction with $\mathbf{1 0}$ and different silyl ketene acetals $11 \mathrm{a}-\mathbf{d}$ and yielding in 12 $\left(\right.$ Scheme 6) ${ }^{\mathrm{a}}$

\begin{tabular}{lllll} 
entry & catalyst & $\mathrm{SiR}_{3}$ & yield [\%] & ee [\%] \\
\hline 1 & $\mathbf{8}$ & 11a TMS & 56 & 3 S-12 \\
2 & $\mathbf{8}$ & 11b TES & 42 & $4 \mathrm{~S}-12$ \\
3 & $\mathbf{8}$ & 11c TIPS & 60 & $4 \mathrm{~S}-12$ \\
4 & $\mathbf{8}$ & 11d TBDMS & 46 & $2 \mathrm{~S}-12$ \\
5 & $\mathbf{9}$ & 11a TMS & 73 & $6 \boldsymbol{R}-12$ \\
6 & $\mathbf{9}$ & 11b TES & 67 & 2 $\boldsymbol{R}-12$ \\
7 & $\mathbf{9}$ & 11c TIPS & 52 & $12 \mathrm{~S}-12$ \\
8 & $\mathbf{9}$ & 11d TBDMS & 72 & $2 \boldsymbol{R}-12$ \\
9 & - & 11c TIPS & 0 & - \\
\hline
\end{tabular}

aReactions carried out with $0.1 \mathrm{mmol} 16,0.11 \mathrm{mmol} 17,0.15 \mathrm{mmol}$ 11a-d and $20 \mathrm{~mol} \%$ cat in $4 \mathrm{~mL}$ toluene at $-60^{\circ} \mathrm{C}$; bisolated yields; ${ }^{c}$ chiral HPLC OD-H, $n$-hexane/iPrOH 90:10, $1 \mathrm{~mL} / \mathrm{min}, 220 \mathrm{~nm}, 25^{\circ} \mathrm{C}$, $(-)-12$ correlates to $(S)-12[45,76]$.
Table 10: Hydrogen-bond-catalyzed addition of silyl ketene acetals 11a-d with 1-chloroisochroman (18) to product 19 with chlorosilanol 8 and silanediol 9 in different solvents ${ }^{a}$ (Scheme 7).

\begin{tabular}{llllll} 
entry & cat. & solvent & SiR & yield [\%] & ee [\%] \\
\hline 1 & $\mathbf{9}$ & toluene & 11a TMS & 0 & - \\
2 & $\mathbf{9}$ & MTBE & 11a TMS & 0 & - \\
3 & $\mathbf{9}$ & THF & 11a TMS & 0 & - \\
4 & $\mathbf{9}$ & diethyl ether & 11a TMS & 0 & - \\
5 & $\mathbf{9}$ & DCM & 11a TMS & 85 & 1 \\
6 & $\mathbf{9}$ & DCM & 11b TES & 37 & 3 \\
7 & $\mathbf{9}$ & DCM & 11c TIPS & 12 & 5 \\
8 & $\mathbf{9}$ & DCM & 11d TBDMS & 8 & 3 \\
9 & $\mathbf{8}$ & DCM & 11a TMS & 54 & 0 \\
10 & $\mathbf{8}$ & DCM & 11b TES & 46 & 2 \\
11 & $\mathbf{8}$ & DCM & 11c TIPS & 16 & 5 \\
12 & $\mathbf{8}$ & DCM & 11d TBDMS & 12 & 3 \\
13 & - & DCM & 11a TMS & 58 & - \\
14 & $\mathbf{-}$ & DCM & 11c TIPS & 5 & - \\
\hline
\end{tabular}

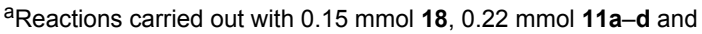
$20 \mathrm{~mol} \%$ cat in $1.2 \mathrm{~mL}$ solvent at $-60{ }^{\circ} \mathrm{C}$; bisolated yields; ${ }^{\mathrm{c}}$ chiral HPLC OD-H, $n$-hexane/iPrOH 100:0, $1.0 \mathrm{~mL} / \mathrm{min}, 210 \mathrm{~nm}, 25^{\circ} \mathrm{C}$, $(-)-18$ correlates to $(S)-18$ [77].

analogue to the $N$-acyl Mannich reaction (Scheme 6 vs Scheme 7). The catalyst abstracts and binds the chloride anion and forms an ion pair [cat $\left.{ }^{\bullet} \mathrm{Cl}\right]^{-}$and oxocarbenium ion $[\mathbf{1 8}]^{+}$. Silyl ketene acetal 11 reacts with this ion pair complex to product 19 [77,78]. Only with DCM as solvent, product 19 of the reaction has been isolated (Table 10). Silanediol 9 and silyl ketene acetal 11a provide the highest yield (85\%, Table 10 , entry 5). The substitution pattern on the silyl ketene has a direct influence on the yield.

The highest yield is reached with TMS substitution (silanediol 9, $85 \%$ yield, Table 10, entry 5; chlorosilanol 8, 54\% yield, Table 10, entry 9). The yield decreases as the substituents

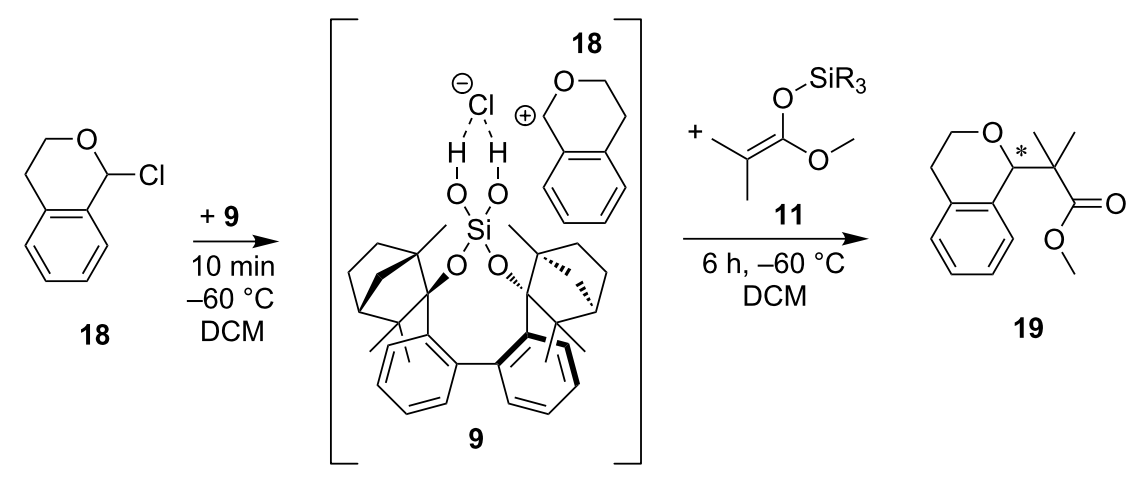

Scheme 7: Hydrogen-bond-catalyzed nucleophilic substitution of 18 with BIFOXSi(OH) $)_{2}(\mathbf{9})$ and nucleophile silyl ketene acetals 11.18 and 9 form an activated electrophile ion pair complex which yields $C-C$ coupling product 19 (Table 10). 
become larger (Table 10, entries 6-8, 10 and 11). This trend can also be seen in the uncatalyzed reaction (Table 10, entries 13, 14). Only for 11c and silandiol 9 a considerable ee with $5 \%$ is determined (Table 10, entries 7 and 11). Chlorosilanol 8 does not show catalytic activity for the reaction of $\mathbf{1 8}$ with $\mathbf{1 1 a}$, as the background reaction is slightly faster (54\% vs $58 \%$, Table 10, entries 9 and 13). With increasing of the steric demand of the nucleophilic silyl group, the background reaction slows down and chlorosilanol $\mathbf{8}$ has a positive influence on the yields and the enantiomeric excess.

In a third reaction, the 1,4 addition of silyl keten acetals $\mathbf{1 1}$ to chromone 20 is investigated (Table 11, Scheme 8). Chromone 20 is first transformed to the oxonium ion pair 21. Catalyst $\mathrm{BIFOXSi}(\mathrm{OH})_{2}(9)$ binds the triflate anion via hydrogen bonding and leaves the pyrylium derivative $\mathbf{2 1}$ for the nucleophilic attack of silyl keten acetals $\mathbf{1 1}$ to form product $\mathbf{2 2}$ (Scheme 8).

With BIFOXSi(OH) 2 (9) an increase of yield (71\% yield, $4 \%$ ee, Table 11 , entry 2 ) compared to the not catalyzed reaction $(48 \%$, Table 11 , entry 10$)$ is achieved. BIFOXSiCl(OH) (8) has no activation ability, but little effect on the ee ( $46 \%$ yield, $1 \%$ ee, Table 11 , entry 6$)$. Here, the sterically demanding silyl keten acetals increase yields. With $\operatorname{BIFOXSi}(\mathrm{OH})_{2}(9)$, the bulkiest acetal 11d yields $98 \%$ and the smallest 11a yields $60 \%$ of product 22 (Table 11, entries 1-4). This tendency is the same for $\mathrm{BIFOXSiCl}(\mathrm{OH})(\mathbf{8}$, Table 11, entries 5-8), with exception of acetal 11a, which yields $55 \%$ of product 22. Mattson et al. used 2,6-di-tert-butyl-4-methylpyridine as additive [48]. It is added at the beginning to the reaction, so it should support the formation of the ion pair 21. As organic base it binds also to

\begin{tabular}{|c|c|c|c|c|}
\hline entry & catalyst & $\mathrm{SiR}_{3}$ & yield [\%] & ee $[\%]^{c}$ \\
\hline 1 & 9 & 11d TBDMS & 98 & 1 \\
\hline 2 & 9 & 11c TIPS & 71 & 4 \\
\hline 3 & 9 & 11b TES & 69 & 1 \\
\hline 4 & 9 & 11a TMS & 60 & 0 \\
\hline 5 & 8 & 11d TBDMS & 70 & 0 \\
\hline 6 & 8 & 11c TIPS & 46 & 1 \\
\hline 7 & 8 & 11b TES & 35 & 1 \\
\hline 8 & 8 & 11a TMS & 55 & 1 \\
\hline $9^{d}$ & 9 & 11c TIPS & 50 & 2 \\
\hline $10^{e}$ & - & 11c TIPS & 48 & - \\
\hline
\end{tabular}

aReactions carried out with $0.15 \mathrm{mmol} 20,0.22 \mathrm{mmol} 11 \mathrm{a}-\mathrm{d}$ and $20 \mathrm{~mol} \%$ cat in $4 \mathrm{~mL}$ toluene at $-80^{\circ} \mathrm{C}$; bisolated yields; ${ }^{c}$ chiral HPLC AD-H, $n$-hexane/iPrOH 98:2, $1 \mathrm{~mL} / \mathrm{min}, 254 \mathrm{~nm}, 25^{\circ} \mathrm{C}$, (+)-22 correlates to (S)-22 [48]; d with 20 mol \% 2.6-di-tert-butyl-4-methylpyridine as additive for step 1 (Scheme 8 ); ${ }^{\text {without catalyst. }}$

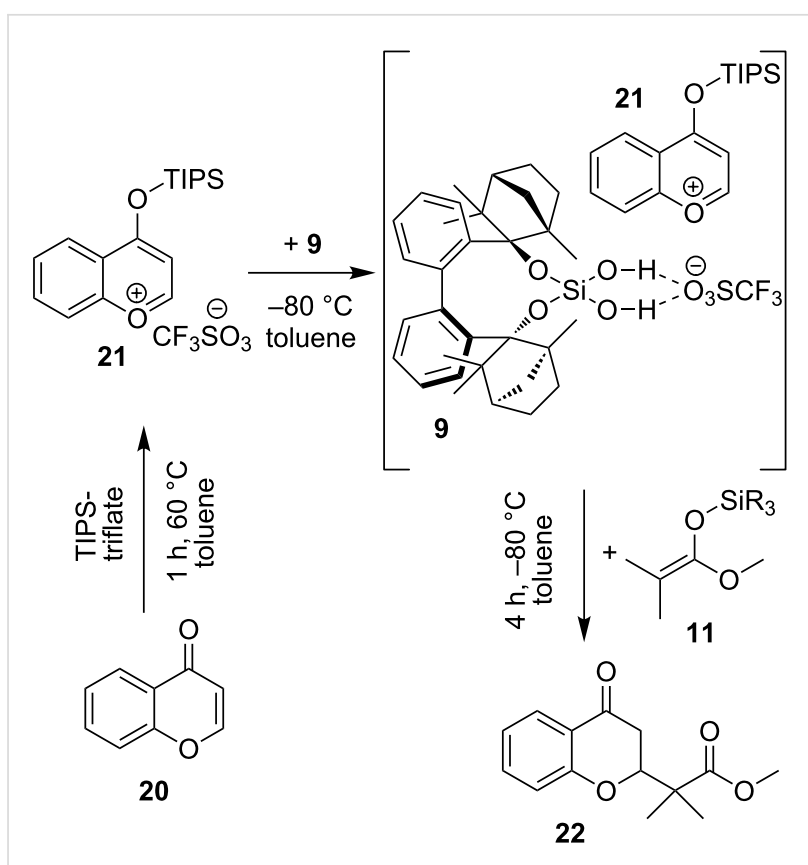

Scheme 8: Nucleophilic substitution of 20 with $\operatorname{BIFOXSi(OH})_{2}(\mathbf{9})$ and nucleophile silyl ketene acetals 11, 20 and 9 form an activated electrophile ion pair complex which yields $\mathrm{C}-\mathrm{C}$ coupling product $\mathbf{2 2}$ (Table 11).

$\operatorname{BIFOXSi}(\mathrm{OH})_{2}(9)$, which results in a lower yield and ee (Table 11 , entry 9).

\section{Conclusion}

Enantiopure fenchole-based silanediol BIFOXSi(OH) $)_{2}(\mathbf{9}$, Figure 1) and chlorosilanol $\operatorname{BIFOXSiCl}(\mathrm{OH})(\mathbf{8}$, Figure 1) are efficiently accessible from BIFOL (5) via enforced hydrolysis of dichlorosilane 7, i.e., $\mathrm{H}_{2} \mathrm{O}$ /THF reflux, $19 \mathrm{~h}$ (Scheme 3, Figure 2).

DFT computations reveal two different hydrolysis mechanisms and explain the unusual low reactivity of $\mathrm{BIFOXSiCl}_{2}(7)$ and BIFOXSiCl $(\mathrm{OH})(\mathbf{8}$, Table 3$)$ with sterically demanding endo fenchone groups. For BIFOXSiCl(OH) (8) two isomers $\left(\mathbf{8}_{\text {eq }}\right.$ vs $\mathbf{8}_{\mathbf{a x}}$ ) are found computationally. Chlorosilanol $\mathbf{8}_{\mathbf{a x}}$, with the axial $\mathrm{Si}-\mathrm{OH}$ alignment, is the thermodynamically more stable isomer $\left(\Delta E_{\mathrm{r}}=2.7 \mathrm{kcal} \mathrm{mol}^{-1}\right.$, Table 3), in accordance with $\mathrm{X}$-ray crystal structure analyses of 8 (Figure 13). The first hydrolysis has a higher activation barrier than the second step, and thus appears to be rate-determining.

In the X-ray crystal structures of BIFOXSiCl(OH) (8, Figure 13) and $\mathrm{BIFOXSi}(\mathrm{OH})_{2}(\mathbf{9}$, Figures 14-16), intermolecular hydrogen bonds are apparent. The lengths of these hydrogen bonds vary from 1.88(3) to 2.16(2) $\AA$ (Table 5). The longest bond appears between $\mathrm{BIFOXSiCl}(\mathrm{OH})(8)$ and acetone (Figure 17). This suggests that $\operatorname{BIFOXSiCl}(\mathrm{OH})(\mathbf{8})$ is the 
weaker hydrogen bond donor, compared to $\operatorname{BIFOXSi(OH})_{2}(\mathbf{9})$. This is additionally supported by UV-vis titrations of chloride with $\mathrm{BIFOXSiCl}(\mathrm{OH})\left(\mathbf{8}, 451.1(4 \%) \mathrm{M}^{-1}\right)$ and $\operatorname{BIFOXSi}(\mathrm{OH})_{2}$ $\left(\mathbf{9}, 5274.9(13 \%) \mathrm{M}^{-1}\right.$, Table 6).

Both new hydrogen bond catalysts can be used for the $\mathrm{C}-\mathrm{C}$ coupling in the $N$-acyl Mannich reaction with activated isochinolin 10, 1-chloroisochroman (18) and chromone 21 with different silyl ketene acetals. Due to more efficient bifunctional $\mathrm{Si}(\mathrm{OH})_{2}-$ hydrogen bonding, silandiol 9 tops chlorosilanol $\mathbf{8}$, also on catalytic application.

\section{Computational Details}

In this work computations were performed using GAUSSIAN 09 [79]. Geometry optimizations and frequency computations were performed at the B3LYP-D3BJ/6-31G(d) level of theory. Zero-point energies were scaled by 0.96 [80]. Single point energies were performed at the M06-2X-D3/6-311++G(d,p) level of theory using the PCM method.

\section{Experimental}

General considerations: All reactions were carried out under an argon atmosphere by using Schlenk techniques, unless otherwise stated. Solvents used in chemical conversions were dried by standard methods and distilled under argon prior to use unless otherwise specified. NMR spectra were recorded on a Bruker Avance II 300 instrument. UV-vis spectra were recorded by using a Perkin Elmer Lambda35 spectrometer. The samples were placed in quartz cells of $1 \mathrm{~cm}$ path length. NMR spectra, UV-vis spectra, crystal data and the coordinates of computed stationary points/transition states, as well as experimental details can be found in Supporting Information File 1. CCDC-1833170 (BIFOXSiCl 2 (7)), CCDC-1833171 (BIFOXSiCl(OH) (8)), CCDC-1833172 (BIFOXSi(OH) 2 (9, dimer)), CCDC-1833173 (BIFOXSi(OH) 2 (9, tetramer)), CCDC-1833174 (BIFOXSiCl(OH) 8-acetone) and CCDC$1833175\left(\mathrm{BIFOXSi}(\mathrm{OH})_{2} \mathbf{9}\right.$-acetone) contain the supplementary crystallographic data for this paper. These data can be obtained free of charge from The Cambridge Crystallographic Data Centre via http://www.ccdc.cam.ac.uk/data_request/cif.

Synthesis of BIFOXSiCl $_{\mathbf{2}}$ (7): In a dried Schlenk flask BIFOL $(5,2.3 \mathrm{~g}, 5 \mathrm{mmol}$. 1 equiv) was solved in THF $(25 \mathrm{~mL})$ in an inert gas atmosphere. After cooling to $0{ }^{\circ} \mathrm{C}, n$-BuLi $(4 \mathrm{~mL}$, $10 \mathrm{mmol}, 2$ equiv, $2.5 \mathrm{M}$ in $n$-hexane) was slowly added. The solution was stirred for $30 \mathrm{~min}$ und was allowed to warm up to $20{ }^{\circ} \mathrm{C}$. After cooling to $0{ }^{\circ} \mathrm{C}$ again tetrachlorosilane $(2.86 \mathrm{~mL}$, $25 \mathrm{mmol}, 5$ equiv) was added dropwise. The reaction mixture was warmed to $20^{\circ} \mathrm{C}$ and stirred overnight. Aqueous work-up with saturated $\mathrm{NH}_{4} \mathrm{Cl}$ followed by extracting with $\mathrm{Et}_{2} \mathrm{O}$ (three times) and concentrated in vacuo results in crude product. After purification with silica gel flash column chromatography (100\% $n$-hexane, $\left.R_{\mathrm{f}}: 0.58\right) \mathrm{BIFOXSiCl}_{2}(7)$ was obtained as a white solid (2.5 g, $4.6 \mathrm{mmol}, 92 \%)$; mp $219.4{ }^{\circ} \mathrm{C}$; $[\alpha]_{436}{ }^{20}=-54.90\left(c 0.46, \mathrm{CHCl}_{3}\right) ;{ }^{1} \mathrm{H} \mathrm{NMR}\left(300 \mathrm{MHz}, \mathrm{CDCl}_{3}\right.$, $\left.25{ }^{\circ} \mathrm{C}, \mathrm{TMS}\right) \delta 7.61(\mathrm{dd}, J=8.1,1.1 \mathrm{~Hz}, 2 \mathrm{H}), 7.26-7.19(\mathrm{~m}$, $2 \mathrm{H}), 7.14-7.06(\mathrm{~m}, 2 \mathrm{H}), 6.97(\mathrm{dd}, J=7.7,1.6 \mathrm{~Hz}, 2 \mathrm{H})$, $2.46-2.32(\mathrm{~m}, 4 \mathrm{H}), 1.72-1.60(\mathrm{~m}, 4 \mathrm{H}), 1.56(\mathrm{~s}, 6 \mathrm{H}), 1.46-1.35$ $(\mathrm{m}, 4 \mathrm{H}), 1.25(\mathrm{td}, J=5.2 \mathrm{~Hz}, 2 \mathrm{H}), 0.64(\mathrm{~s}, 6 \mathrm{H}), 0.49(\mathrm{~s}, 6 \mathrm{H})$; ${ }^{13} \mathrm{C}$ NMR $\left(75 \mathrm{MHz}, \mathrm{CDCl}_{3}, 25{ }^{\circ} \mathrm{C}, \mathrm{TMS}\right) \delta 143.20,141.37$, 136.14, 128.83, 125.06, 124.63, 94.59, 55.33, 50.19, 48.39, 44.06, 35.91, 28.89, 23.47, 20.80, 20.74; ${ }^{29} \mathrm{Si} \mathrm{NMR} \mathrm{(60} \mathrm{MHz,}$ $\mathrm{CDCl}_{3}, 25{ }^{\circ} \mathrm{C}$, TMS) $\delta-21.92$.

Synthesis of BIFOXSiCl(OH) (8): In a dried Schlenk flask $\operatorname{BIFOXSiCl}_{2}(7,1 \mathrm{~g}, 1.8 \mathrm{mmol}, 1$ equiv) was solved in THF $(10 \mathrm{~mL})$. Then triethylamine $(0.52 \mathrm{~mL}, 3.6 \mathrm{mmol}, 2$ equiv) and $\mathrm{H}_{2} \mathrm{O}(0.032 \mathrm{~mL}, 1.8 \mathrm{mmol}, 1$ equiv) was added. The reaction mixture was stirred for $20 \mathrm{~h}$ at $20^{\circ} \mathrm{C}$ and concentrated in vacuo. The residue was purified by silica gel flash column chromatography ( $n$-hexane/ethyl acetate: 9:0.5, $R_{\mathrm{f}}: 0.43$ ) which resulted in $\mathrm{BIFOXSiCl}(\mathrm{OH})(8,642.6 \mathrm{mg}, 1.2 \mathrm{mmol}, 67 \%)$ as a white solid and $\operatorname{BIFOXSi}(\mathrm{OH})_{2}(\mathbf{9}, 90.6 \mathrm{mg} .0 .1 \mathrm{mmol} .6 \%)$ as a white solid; mp 105.7-112.5 ${ }^{\circ} \mathrm{C} ;[\alpha]_{589^{20}}=-3.24\left(c\right.$ 0.658, $\left.\mathrm{CHCl}_{3}\right)$; ${ }^{1} \mathrm{H}$ NMR $\left(300 \mathrm{MHz}, \mathrm{CDCl}_{3}, 25^{\circ} \mathrm{C}\right.$, TMS $) \delta 7.73(\mathrm{~d}, J=8.0 \mathrm{~Hz}$, $1 \mathrm{H}), 7.61(\mathrm{dd}, J=7.6,1.7 \mathrm{~Hz}, 1 \mathrm{H}), 7.35-7.17(\mathrm{~m}, 4 \mathrm{H}), 7.03(\mathrm{t}$, $J=7.3 \mathrm{~Hz}, 1 \mathrm{H}), 6.72(\mathrm{dd}, J=7.8,1.5 \mathrm{~Hz}, 1 \mathrm{H}), 2.66-2.48(\mathrm{~m}$, 2H), 2.40 (s, 1H), 2.31 (d, $J=10.5 \mathrm{~Hz}, 1 \mathrm{H}), 1.72(\mathrm{~s}, 3 \mathrm{H}), 1.61$ $(\mathrm{s}, 5 \mathrm{H}), 1.52(\mathrm{~s}, 3 \mathrm{H}), 1.51-1.20(\mathrm{~m}, 6 \mathrm{H}), 0.90(\mathrm{~s}, 3 \mathrm{H}), 0.82(\mathrm{~s}$, $3 \mathrm{H}), 0.45$ (s, 3H), 0.08 (s, 3H); ${ }^{13} \mathrm{C} \mathrm{NMR}\left(75 \mathrm{MHz}, \mathrm{CDCl}_{3}, 25\right.$ ${ }^{\circ} \mathrm{C}$, TMS) $\delta 145.10,144.39,142.08,140.14,137.33,133.86$, $129.25,129.05,128.23,125.63,125.25,124.60,123.70,92.83$, $92.25,56.38,54.22,50.96,49.57,49.31,46.78,43.87,43.78$, $35.80,35.02,29.45,28.36,23.86,23.42,22.28,21.49,20.63$, $19.33,19.18 ;{ }^{29} \mathrm{Si} \mathrm{NMR}\left(60 \mathrm{MHz}, \mathrm{CDCl}_{3}, 25{ }^{\circ} \mathrm{C}\right.$, TMS $) \delta$ -21.93; MS (HRMS ESI) $\mathrm{m} / z$ : $[\mathrm{M}+\mathrm{Na}]^{+}$calcd for $\mathrm{C}_{32} \mathrm{H}_{41} \mathrm{O}_{3} \mathrm{ClNaSi}$, 559.2405; found, 559.2404 (-0.1 ppm).

Synthesis BIFOXSi(OH) 2 (9): In a dried Schlenk flask $\mathrm{BIFOXSiCl}_{2}$ (7, $1 \mathrm{~g}, 1.8 \mathrm{mmol}, 1$ equiv) was solved in THF (25 mL) and $\mathrm{H}_{2} \mathrm{O}(25 \mathrm{~mL})$. The solution was heated to reflux and stirred overnight. Then the solution was concentrated in vacuo and purified by silica gel flash column chromatography ( $n$-hexane/ethyl acetate 9:1, $\left.R_{\mathrm{f}}: 0.26\right)$. $\operatorname{BIFOXSi}(\mathrm{OH})_{2}(9)$ was obtained as white solid (0.78 g, $1.5 \mathrm{mmol}, 84 \%)$; mp $199.4{ }^{\circ} \mathrm{C}$; $[\alpha]_{589}{ }^{20}=24.02\left(c 0.769, \mathrm{CHCl}_{3}\right) ;{ }^{1} \mathrm{H} \mathrm{NMR}\left(300 \mathrm{MHz}, \mathrm{CDCl}_{3}\right.$, $\left.25{ }^{\circ} \mathrm{C}, \mathrm{TMS}\right) \delta 7.60(\mathrm{~d}, J=8.0 \mathrm{~Hz}, 2 \mathrm{H}), 7.20(\mathrm{td}, J=7.8,1.7$ $\mathrm{Hz}, 2 \mathrm{H}), 7.07(\mathrm{td}, J=7.5,1.1 \mathrm{~Hz}, 2 \mathrm{H}), 6.95(\mathrm{dd}, J=7.7,1.5$ Hz, 2H). 2.48-2.19 (m, 4H), 2.03 (d, $J=2.5 \mathrm{~Hz}, 2 \mathrm{H}), 1.70-1.57$ $(\mathrm{m}, 4 \mathrm{H}), 1.49(\mathrm{~s}, 6 \mathrm{H}), 1.43-1.30(\mathrm{~m}, 4 \mathrm{H}), 1.18(\mathrm{td}, J=12.5$, $4.8 \mathrm{~Hz}, 2 \mathrm{H}), 0.59(\mathrm{~s}, 6 \mathrm{H}), 0.45(\mathrm{~s}, 6 \mathrm{H}) ;{ }^{13} \mathrm{C} \mathrm{NMR}(75 \mathrm{MHz}$, $\mathrm{CDCl}_{3}, 25^{\circ} \mathrm{C}$, TMS) $\delta 144.28,141.97,135.16,128.80,124.70$, 
$124.17,90.24,55.04,50.08,48.11,43.98,35.33,29.01,23.65$, 20.85, 19.76; MS (HRMS ESI) $m / z:[\mathrm{M}+\mathrm{Na}]^{+}$calcd for $\mathrm{C}_{32} \mathrm{H}_{42} \mathrm{O}_{4} \mathrm{NaSi}$, 541.2744; found, 541.2742 (-0.4 ppm); ${ }^{29} \mathrm{Si}$ NMR $\left(60 \mathrm{MHz}, \mathrm{CDCl}_{3}, 25{ }^{\circ} \mathrm{C}\right.$, TMS $) \delta-21.92$.

General procedure for the hydrolysis studies of dichlorosilanes 7, 13 and 14: Dichlorosilane $(0.09 \mathrm{mmol})$ was solved in THF (2.5 mL) or THF/ $\mathrm{H}_{2} \mathrm{O}(1.25 \mathrm{~mL} / 1.25 \mathrm{~mL})$. For THF/ $\mathrm{H}_{2} \mathrm{O} /$ $\mathrm{KOH}$ conditions, $\mathrm{KOH}(0.9 \mathrm{mmol}, 50.5 \mathrm{mg}, 10$ equiv) was added. The reaction mixture was heated and stirred as stated. After the reaction time the mixture was extracted two times with diethyl ether $(2 \mathrm{~mL})$ and concentrated in vacuo. The residue was solved in THF $(5 \mathrm{~mL})$. A sample $(0.5 \mathrm{~mL})$ was transferred to a GC vial and $n$-tetradecane solution $(0.01 \mathrm{M}$ in THF, $0.5 \mathrm{~mL}$ ) was added as standard for GC analysis.

General procedure for the $\mathrm{N}$-acyl Mannich reaction of isoquinolin 16 with silyl ketene acetals 11 to product 12: In a heat dried Schlenk tube isoquinolin $(\mathbf{1 6}, 11 \mu \mathrm{L}, 0.1 \mathrm{mmol}$, 1 equiv) was solved in solvent $(4 \mathrm{~mL})$ and cooled to $0{ }^{\circ} \mathrm{C}$ under inert gas atmosphere. To this solution 2,2,2-trichlorethoxycarbonyl chloride ( $15 \mu \mathrm{L}, 0.11 \mathrm{mmol}, 1.1$ equiv) was added. The cooling was removed. The solution warmed to $20^{\circ} \mathrm{C}$ and stirred for $30 \mathrm{~min}$. After this the solution was cooled to reaction temperature. The catalyst was added and stirred for 10 minutes. Then silyl ketene acetall 11 ( $0.15 \mathrm{mmol}, 1.5$ equiv) was added and the reaction mixture stirred for $6 \mathrm{~h}$. The reaction was quenched by adding $\mathrm{NaOMe}(0.2 \mathrm{~mL}, 0.5 \mathrm{M}$ in $\mathrm{MeOH})$, filtered through silica gel with ethyl acetate as eluent and concentrated in vacuo. After further purification by silica gel flash column chromatography ( $n$-hexane/ethyl acetate 95:5) product 12 was obtained. The enantiomeric excess is determined by chiral HPLC analysis (see Supporting Information File 1).

General procedure for addition of silyl ketene acetals 11 to 1-chloroisochroman (18) to product 19: In a heat dried Schlenk tube 1-chloroisochroman (18, $0.15 \mathrm{mmol}, 0.3 \mathrm{~mL}$ of $0.5 \mathrm{M}$ in toluene) was solved in solvent $(1.2 \mathrm{~mL})$ under inert gas atmosphere and cooled to $-60{ }^{\circ} \mathrm{C}$. After this catalyst ( $0.03 \mathrm{mmol}, 0.2$ equiv) was added and stirred for $10 \mathrm{~min}$. Then silyl ketene acetal 11 ( $0.22 \mathrm{mmol}, 1.5$ equiv) was added and the resulting reaction mixture was stirred for $6 \mathrm{~h}$. The reaction was quenched by adding $\mathrm{NaOMe}(0.2 \mathrm{~mL}, 0.5 \mathrm{M}$ in $\mathrm{MeOH})$, concentrated in vacuo and purified by silica gel flash column chromatography ( $n$-hexane/Et $\left.{ }_{2} \mathrm{O} 9: 1\right)$. The enantiomeric excess is determined by chiral HPLC analysis (see Supporting Information File 1).

General procedure for addition of silyl ketene acetals 11 to chromone 20 to product 22: In a heat dried Schlenk tube chromone 20 (14.6 mg, $0.1 \mathrm{mmol}, 1$ equiv) was solved in $2 \mathrm{~mL}$ dried toluene under inert gas atmosphere. TIPSOTf $(29.5 \mu \mathrm{L}$, $0.11 \mathrm{mmol}, 1.1$ equiv) was added and heated to $60{ }^{\circ} \mathrm{C}$ for $1 \mathrm{~h}$. After this, the reaction mixture was cooled to $-80{ }^{\circ} \mathrm{C}$, catalyst ( $0.02 \mathrm{mmol}, 0.2$ equiv) and silyl ketene acetal 11 ( $0.14 \mathrm{mmol}$, 1.25 equiv), solved in $2 \mathrm{~mL}$ dried toluene, were added. The resulting reaction mixture was stirred for $4 \mathrm{~h}$. The reaction was quenched by adding $3 \mathrm{M} \mathrm{HCl}(0.2 \mathrm{~mL})$, concentrated in vacuo and purified by silica gel flash column chromatography ( $n$-hexane/ethyl acetate 9:1). The enantiomeric excess is determined by chiral HPLC analysis (see Supporting Information File 1).

\section{Supporting Information}

\section{Supporting Information File 1}

Copies of all NMR spectra, HPLC graphs, GC graphs of the kinetic study.

[https://www.beilstein-journals.org/bjoc/content/ supplementary/1860-5397-15-17-S1.pdf]

\section{Acknowledgements}

We thank the Fonds der Chemischen Industrie, the Deutsche Forschungsgemeinschaft (DFG GO-930-13), Bayer AG, BASF AG, Wacker AG, Evonic AG, Raschig GmbH, Symrise GmbH, Solvay $\mathrm{GmbH}$, the OMG group, and INEOS-Köln for support. We also thank the computing center of the University of Cologne (RRZK) for providing CPU time on the DFG-funded supercomputer CHEOPS, as well as for support. Special thanks go to Niklas Kolks and Matthias Spilles for their contributions during their practical courses.

\section{References}

1. Chandrasekhar, V.; Boomishankar, R.; Nagendran, S. Chem. Rev. 2004, 104, 5847-5910. doi:10.1021/cr0306135

2. Hernández, D.; Mose, R.; Skrydstrup, T. Org. Lett. 2011, 13, 732-735. doi:10.1021/ol102968g

3. Kim, J. K.; Sieburth, S. M. J. Org. Chem. 2012, 77, 2901-2906. doi:10.1021/jo300175t

4. Madsen, J. L. H.; Andersen, T. L.; Santamaria, S.; Nagase, H.; Enghild, J. J.; Skrydstrup, T. J. Med. Chem. 2012, 55, 7900-7908. doi:10.1021/jm301000k

5. Guan, Y.; Attard, J. W.; Visco, M. D.; Fisher, T. J.; Mattson, A. E. Chem. - Eur. J. 2018, 24, 7123-7127. doi:10.1002/chem.201801304

6. Visco, M. D.; Attard, J.; Guan, Y.; Mattson, A. E. Tetrahedron Lett. 2017, 58, 2623-2628. doi:10.1016/j.tetlet.2017.05.045

7. Plunkett, M. J.; Ellman, J. A. J. Org. Chem. 1995, 60, 6006-6007. doi:10.1021/jo00124a005

8. Anderson, T. F.; Statham, M. A. J.; Carroll, M. A. Tetrahedron Lett. 2006, 47, 3353-3355. doi:10.1016/j.tetlet.2006.03.095

9. Glekas, A.; Sieburth, S. M. Tetrahedron Lett. 2001, 42, 3799-3801. doi:10.1016/s0040-4039(01)00576-7

10. Duong, H. Q.; Sieburth, S. M. J. Org. Chem. 2018, 83, 5398-5409. doi:10.1021/acs.joc.8b00116 
11. Yao, C.; Yu, J.; Wang, Y.; Tang, C.; Huang, C. Dent. Mater. 2018, 34, 809-818. doi:10.1016/j.dental.2018.02.004

12. Carilla, J.; Fajarí, L.; Juliá, L.; Riera, J.; Lloveras, J.; Verdaguer, N.; Fita, I. J. Organomet. Chem. 1992, 423, 163-171. doi:10.1016/0022-328x(92)83111-t

13. Bruña, S.; Garrido-Castro, A. F.; Perles, J.; Montero-Campillo, M. M.; Mó, O.; Kaifer, A. E.; Cuadrado, I. Organometallics 2016, 35, 3507-3519. doi:10.1021/acs.organomet.6b00559

14. Auner, N.; Probst, R.; Heikenwälder, C.-R.; Herdtweck, E.; Gamper, S.; Müller, G. Z. Naturforsch., B: J. Chem. Sci. 1993, 48, 1625-1634. doi:10.1515/znb-1993-1123

15. Belzner, J.; Schär, D.; Herbst-Irmer, R.; Kneisel, B. O.; Noltemeyer, M. Tetrahedron 1998, 54, 8481-8500. doi:10.1016/s0040-4020(98)00451-7

16. Hurkes, N.; Belaj, F.; Koe, J. R.; Pietschnig, R. Appl. Organomet. Chem. 2018, 32, e4427. doi:10.1002/aoc.4427

17. Shamaev, A. E.; Glazkov, A. A.; Ignatenko, A. V.; Sakharov, A. M. Russ. Chem. Bull. 2005, 54, 1250-1253. doi:10.1007/s11172-005-0389-y

18. Safa, K. D.; Asadi, A.; Sargordan, M. J. Organomet. Chem. 1997, 545-546, 61-65. doi:10.1016/s0022-328x(97)00302-1

19. George, P. D.; Sommer, L. H.; Whitmore, F. C. J. Am. Chem. Soc. 1953, 75, 1585-1588. doi:10.1021/ja01103a020

20. Cusa, N. W.; Kipping, F. S. J. Chem. Soc. 1932, 2205-2209. doi:10.1039/jr9320002205

21. Ojima, I.; Fuchikami, T.; Yatabe, M. J. Organomet. Chem. 1984, 260, 335-346. doi:10.1016/s0022-328x(00)99483-x

22. Robinson, R.; Kipping, F. S. J. Chem. Soc., Trans. 1912, 101, 2142-2155. doi:10.1039/ct9120102142

23. Shaffer, L. H.; Flanigen, E. M. J. Phys. Chem. 1957, 61, 1591-1595. doi:10.1021/j150558a004

24. Shaffer, L. H.; Flanigen, E. M. J. Phys. Chem. 1957, 61, 1595-1600. doi:10.1021/j150558a005

25. Swain, C. G.; Esteve, R. M.; Jones, R. H. J. Am. Chem. Soc. 1949, 71, 965-971. doi:10.1021/ja01171a056

26. Doyle, A. G.; Jacobsen, E. N. Chem. Rev. 2007, 107, 5713-5743. doi:10.1021/cr068373r

27. Taylor, M. S.; Jacobsen, E. N. Angew. Chem., Int. Ed. 2006, 45, 1520-1543. doi:10.1002/anie.200503132

28. Auvil, T. J.; Schafer, A. G.; Mattson, A. E. Eur. J. Org. Chem. 2014 2633-2646. doi:10.1002/ejoc.201400035

29. Alemán, J.; Parra, A.; Jiang, H.; Jørgensen, K. A. Chem. - Eur. J. 2011, 17, 6890-6899. doi:10.1002/chem.201003694

30. Zhang, Z.; Schreiner, P. R. Chem. Soc. Rev. 2009, 38, 1187-1198. doi:10.1039/b801793j

31. Takemoto, Y. Chem. Pharm. Bull. 2010, 58, 593-601. doi:10.1248/cpb.58.593

32. Klare, H.; Neudörfl, J. M.; Goldfuss, B. Beilstein J. Org. Chem. 2014, 10, 224-236. doi:10.3762/bjoc.10.18

33. Klare, H.; Hanft, S.; Neudörfl, J. M.; Schlörer, N. E.; Griesbeck, A.; Goldfuss, B. Chem. - Eur. J. 2014, 20, 11847-11855. doi:10.1002/chem.201403013

34. Wolf, F. F.; Klare, H.; Goldfuss, B. J. Org. Chem. 2016, 81, 1762-1768. doi:10.1021/acs.joc.5b02167

35. Wolf, F. F.; Neudörfl, J.-M.; Goldfuss, B. New J. Chem. 2018, 42, 4854-4870. doi:10.1039/c7nj04660j

36. Kondo, S.-i.; Okada, N.; Tanaka, R.; Yamamura, M.; Unno, M. Tetrahedron Lett. 2009, 50, 2754-2757.

doi:10.1016/j.tetlet.2009.03.134
37. Busschaert, N.; Caltagirone, C.; Van Rossom, W.; Gale, P. A. Chem. Rev. 2015, 115, 8038-8155. doi:10.1021/acs.chemrev.5b00099

38. Brak, K.; Jacobsen, E. N. Angew. Chem., Int. Ed. 2013, 52, 534-561. doi:10.1002/anie.201205449

39. Kondo, S.-i.; Harada, T.; Tanaka, R.; Unno, M. Org. Lett. 2006, 8 , 4621-4624. doi:10.1021/ol061822p

40. Liu, M.; Tran, N. T.; Franz, A. K.; Lee, J. K. J. Org. Chem. 2011, 76, 7186-7194. doi:10.1021/jo201214x

41. Tran, N. T.; Min, T.; Franz, A. K. Chem. - Eur. J. 2011, 17, 9897-9900. doi:10.1002/chem.201101492

42. Tran, N. T.; Wilson, S. O.; Franz, A. K. Org. Lett. 2012, 14, 186-189. doi:10.1021/ol202971m

43. Tran, N. T.; Wilson, S. O.; Franz, A. K. Chem. Commun. 2014, 50, 3738-3740. doi:10.1039/c4cc00672k

44. Wilson, S. O.; Tran, N. T.; Franz, A. K. Organometallics 2012, 31 , 6715-6718. doi:10.1021/om300736n

45. Schafer, A. G.; Wieting, J. M.; Fisher, T. J.; Mattson, A. E. Angew. Chem., Int. Ed. 2013, 52, 11321-11324. doi:10.1002/anie.201305496

46. Schafer, A. G.; Wieting, J. M.; Mattson, A. E. Org. Lett. 2011, 13, 5228-5231. doi:10.1021/ol2021115

47. Wieting, J. M.; Fisher, T. J.; Schafer, A. G.; Visco, M. D.; Gallucci, J. C.; Mattson, A. E. Eur. J. Org. Chem. 2015, 525-533. doi:10.1002/ejoc.201403441

48. Hardman-Baldwin, A. M.; Visco, M. D.; Wieting, J. M.; Stern, C.; Kondo, S.-i.; Mattson, A. E. Org. Lett. 2016, 18, 3766-3769. doi:10.1021/acs.orglett.6b01783

49. Kondo, S.-i.; Bie, Y.; Yamamura, M. Org. Lett. 2013, 15, 520-523. doi:10.1021/ol303332k

50. Schott, G.; Engelbrecht, L.; Holdt, H. J. Z. Anorg. Allg. Chem. 1979, 459, 177-186. doi:10.1002/zaac. 19794590119

51. Beckmann, J.; Dakternieks, D.; Duthie, A.; Larchin, M. L.; Tiekink, E. R. T. Appl. Organomet. Chem. 2003, 17, 52-62. doi:10.1002/aoc.380

52. Alpagut, Y.; Goldfuss, B.; Neudörfl, J.-M. Beilstein J. Org. Chem. 2008, 4, No. 25. doi:10.3762/bjoc.4.25

53. Kop-Weiershausen, T.; Lex, J.; Neudörfl, J.-M.; Goldfuss, B. Beilstein J. Org. Chem. 2005, 1, No. 6. doi:10.1186/1860-5397-1-6

54. Lange, D. A.; Neudörfl, J.-M.; Goldfuss, B. Tetrahedron 2006, 62, 3704-3709. doi:10.1016/j.tet.2006.01.060

55. Goldfuss, B.; Löschmann, T.; Kop-Weiershausen, T.; Neudörfl, J.; Rominger, F. Beilstein J. Org. Chem. 2006, 2, No. 7. doi:10.1186/1860-5397-2-7

56. Trillo, R. B.; Leven, M.; Neudörfl, J. M.; Goldfuss, B. Adv. Synth. Catal. 2012, 354, 1451-1465. doi:10.1002/adsc.201100924

57. Soki, F.; Neudörfl, J.-M.; Goldfuss, B. J. Organomet. Chem. 2008, 693, 2139-2146. doi:10.1016/j.jorganchem.2008.03.013

58. Blanco Trillo, R.; Neudörfl, J. M.; Goldfuss, B. Beilstein J. Org. Chem. 2015, 11, 313-322. doi:10.3762/bjoc.11.36

59. Schubert, U.; Neugebauer, W.; von Ragué Schleyer, P. J. Chem. Soc., Chem. Commun. 1982, 1184-1185. doi:10.1039/c39820001184

60. Spirk, S.; Nieger, M.; Rechberger, G. N.; Pietschnig, R. Appl. Organomet. Chem. 2006, 20, 683-686. doi:10.1002/aoc.1117

61. Schäfer, A.; Weidenbruch, M.; Pohl, S.; Saak, W. Z. Naturforsch., B: J. Chem. Sci. 1990, 45, 1363-1368. doi:10.1515/znb-1990-1004

62. Bento, A. P.; Bickelhaupt, F. M. J. Org. Chem. 2007, 72, 2201-2207. doi:10.1021/jo070076e 
63. Hamlin, T. A.; van Beek, B.; Wolters, L. P.; Bickelhaupt, F. M. Chem. - Eur. J. 2018, 24, 5927-5938. doi:10.1002/chem.201706075

64. Hupf, E.; Olaru, M.; Raț, C. I.; Fugel, M.; Hübschle, C. B.; Lork, E.; Grabowsky, S.; Mebs, S.; Beckmann, J. Chem. - Eur. J. 2017, 23, 10568-10579. doi:10.1002/chem.201700992

65. Ignatov, S. K.; Sennikov, P. G.; Razuvaev, A. G.; Chuprov, L. A.; Schrems, O.; Ault, B. S. J. Phys. Chem. A 2003, 107, 8705-8713. doi:10.1021/jp034618h

66. Ignatyev, I. S.; Schaefer, H. F. Organometallics 2001, 20, 3113-3121. doi:10.1021/om010181t

67. Chipanina, N. N.; Lazareva, N. F.; Oznobikhina, L. P.; Lazarev, I. M.; Shainyan, B. A. Comput. Theor. Chem. 2015, 1070, 162-173. doi:10.1016/j.comptc.2015.08.008

68. Matsubara, T.; Ito, T. J. Phys. Chem. A 2016, 120, 2636-2646. doi:10.1021/acs.jpca.6b02308

69. Cossi, M.; Barone, V.; Cammi, R.; Tomasi, J. Chem. Phys. Lett. 1996, 255, 327-335. doi:10.1016/0009-2614(96)00349-1

70. Mennucci, B.; Cancès, E.; Tomasi, J. J. Phys. Chem. B 1997, 101, 10506-10517. doi:10.1021/jp971959k

71. Koch, W.; Holthausen, M. C. A chemist's guide to density functional theory, 5. reprint, 2nd ed.; Wiley-VCH: Weinheim, 2008.

72. Grunenberg, J. Chem. Sci. 2015, 6, 4086-4088. doi:10.1039/c5sc01322d

73. West, R.; Baney, R. H. J. Am. Chem. Soc. 1959, 81, 6145-6148. doi:10.1021/ja01532a011

74. Steiner, T. Angew. Chem., Int. Ed. 2002, 41, 48-76. doi:10.1002/1521-3773(20020104)41:1<48::aid-anie48>3.0.co;2-u

75. Thordarson, P. Chem. Soc. Rev. 2011, 40, 1305-1323. doi:10.1039/c0cs00062k

76. Taylor, M. S.; Tokunaga, N.; Jacobsen, E. N. Angew. Chem., Int. Ed. 2005, 44, 6700-6704. doi:10.1002/anie.200502277

77. Reisman, S. E.; Doyle, A. G.; Jacobsen, E. N. J. Am. Chem. Soc. 2008, 130, 7198-7199. doi:10.1021/ja801514m

78. Berkessel, A.; Das, S.; Pekel, D.; Neudörfl, J.-M. Angew. Chem., Int. Ed. 2014, 53, 11660-11664. doi:10.1002/anie.201403778

79. Gaussian 09, Rev. D.01; Gaussian, Inc.: Wallingford CT, 2013.

80. NIST Computational Chemistry Comparison and Benchmark Database. NIST Standard Reference Database Number 101. http://cccbdb.nist.gov/.

\section{License and Terms}

This is an Open Access article under the terms of the Creative Commons Attribution License (http://creativecommons.org/licenses/by/4.0). Please note that the reuse, redistribution and reproduction in particular requires that the authors and source are credited.

The license is subject to the Beilstein Journal of Organic Chemistry terms and conditions: (https://www.beilstein-journals.org/bjoc)

The definitive version of this article is the electronic one which can be found at: doi:10.3762/bjoc. 15.17 